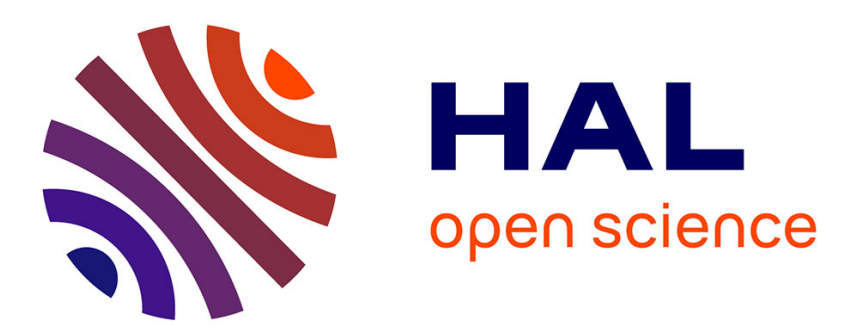

\title{
Integrated treatment of tailing material for the selective recovery of uranium, rare earth elements and heavy metals
}

\author{
Mohammed F. Hamza, Ibrahim E. El-Aassy, Eric Guibal
}

\section{To cite this version:}

Mohammed F. Hamza, Ibrahim E. El-Aassy, Eric Guibal. Integrated treatment of tailing material for the selective recovery of uranium, rare earth elements and heavy metals. Minerals Engineering, 2019, 133, pp.138-148. 10.1016/j.mineng.2019.01.008 . hal-02425057

\section{HAL Id: hal-02425057 \\ https://hal.science/hal-02425057}

Submitted on 4 Feb 2020

HAL is a multi-disciplinary open access archive for the deposit and dissemination of scientific research documents, whether they are published or not. The documents may come from teaching and research institutions in France or abroad, or from public or private research centers.
L'archive ouverte pluridisciplinaire HAL, est destinée au dépôt et à la diffusion de documents scientifiques de niveau recherche, publiés ou non, émanant des établissements d'enseignement et de recherche français ou étrangers, des laboratoires publics ou privés. 


\title{
Integrated treatment of tailing material for the selective recovery of uranium, rare earth elements and heavy metals
}

\author{
Mohammed F. Hamza ${ }^{\mathrm{a}, *}$, Ibrahim E. El-Aassy ${ }^{\mathrm{a}}$, Eric Guibal ${ }^{\mathrm{b}, *}$ \\ ${ }^{\text {a }}$ Nuclear Materials Authority, POB. 530-El Maadi, Cairo, Egypt \\ ${ }^{\mathrm{b}}$ C2MA, IMT - Mines Ales, Univ. Montpellier, Alès cedex, France
}

\begin{abstract}
A B S T R A C T
Processed ores may contain substantial amounts of residual valuable metals. In the case of the mining wastes issued from the exploitation of gibbsite bearing shale ore in the Southwestern Sinai, the characterization of the residue shows the presence of uranium, rare-earth elements (REEs), aluminum and zinc that can be valorized. Pug leaching at $120^{\circ} \mathrm{C}$ with an acid consumption of about $200 \mathrm{~kg} \mathrm{H}_{2} \mathrm{SO}_{4}$ per ton of ore succeeded in leaching more than $94 \%$ of U(VI) and REEs (in addition to substantial amounts of $\mathrm{Al}(\mathrm{III})$ and $\mathrm{Zn}(\mathrm{II})$ ). A series of selective precipitation steps allowed successively recovering (almost quantitatively) $\mathrm{Zn}$ (II), $\mathrm{Fe}$ (III) and $\mathrm{Al}(\mathrm{III})$. In a second step, a magnetic resin has been used for enriching the pregnant leaching solution (by a factor close to 19) through sorption/desorption steps. In the last stage of the process, REEs were recovered by selective precipitation using $25 \%(\mathrm{w} / \mathrm{w})$ oxalate solution at $\mathrm{pH} 1.5$, while uranium was fully recovered by precipitation with $\mathrm{NaOH}$ at $\mathrm{pH}$ 9. Energy dispersive X-ray analysis performed on the different precipitates showed purity grades systematically superior to $93 \%$.
\end{abstract}

\author{
Keywords: \\ Uranium \\ Rare-earth elements \\ Ore residue \\ Acidic leaching \\ Selective precipitation \\ Sorption/desorption \\ Metal recovery
}

\section{Introduction}

The industrial demand for rare-earth elements (REEs) is drastically increasing due to the wide use of these metals in high-tech industry (nuclear energy, photonics, electronics, supermagnets, special alloys, etc.) (Haque et al., 2014). The depletion of limited resources, the regional localization of the production (which can make it a geopolitical and economical "weapon") may explain that the recovery of these critical metals became a strategic research area (Charalampides et al., 2015). In many countries incentive politics have been published for stimulating the recovery of rare, precious and strategic metals from spent equipment and secondary sources (Binnemans et al., 2015; Tunsu et al., 2015; USEPA, 2012). Uranium is a critical resource for nuclear industry and there is a clear need for recovering this metal from nonconventional resources (Gabriel et al., 2013). The valuation of phosphate rocks or alternative mineral resources (including mining residues) is retaining an increasing attention with the objective of recovering valuable metals but also with additional benefits such as a decrease of the environmental impact of mining residue deposits.

These reasons may explain the recent attention paid in Egypt to the re-treatment of the residues of mining exploitation of the gibbsitebearing shales from Um Bogma Formation (located in the area of Abu Mogherate, South Western Sinai, in Egypt) (Figure AM1, see Additional
Material Section). These minerals are issued from the lateritization of pre-existing rocks. These gibbsite ores are rich in $\mathrm{Al}$ (primary target resource) but they also contain significant levels of $\mathrm{Mn}, \mathrm{Zn}, \mathrm{Co}, \mathrm{Cu}, \mathrm{Ni}$, $\mathrm{V}, \mathrm{U}$ and REEs. The $\mathrm{U}$ and REE contents in the original ore are close to $250 \mathrm{ppm}$ and $789 \mathrm{ppm}$, respectively (Hamza, 2010). The acid leaching consisted of metal dissolution using sulfuric acid with an amount of acid close to $210 \mathrm{~kg} \mathrm{H}_{2} \mathrm{SO}_{4}$ per ton of ore. The residue of this primary acidic treatment is still containing substantial amounts of valuable metals (Table 1). The main REEs present in the reprocessed ore are: $\mathrm{Nd}$ (6.52\%, w \%), Pr (3.2\%), Sm (2.56\%), La (1.1\%). Traces of Ce are also detected but not accurately quantified due to lack of precision.

The recovery of metals from ores or residues involved, among others, bioleaching (Abhilash et al., 2009; Brisson et al., 2016; Mishra et al., 2009; Watling, 2015; Zammit et al., 2014) and/or chemical leaching (Mirjalili and Roshani, 2007; Nettleton et al., 2015; Satybaldiyev et al., 2015) (Borra et al., 2015). Depending on the ore grade, the concentration of the metal ions in the leachates may strongly vary and different processes can be used for metal recovery. For effluents containing relatively high metal concentrations, metal precipitation can proceed through chemical precipitation (Aydin and Soylak, 2007; Biswas et al., 2015; Burns et al., 2016; Panda et al., 2014; Weterings and Janssen, 1985; Yoon et al., 2015) or biological precipitation (Kikot et al., 2010; Van Roy et al., 2006). Solvent extraction

\footnotetext{
* Corresponding authors.

E-mail addresses: m_fouda21@hotmail.com (M.F. Hamza), eric.guibal@mines-ales.fr (E. Guibal).
} 
Table 1

Chemical composition of the reprocessed ore material residue, herein considered as the raw material (the ore was initially leached at the mining site by sulfuric acid treatment; $210 \mathrm{Kg} \mathrm{H}_{2} \underline{\mathrm{SO}}_{4}$ /ton ore at $\left.22{ }^{\circ} \mathrm{C}( \pm 2)\right)(\mathrm{Hamza}, 2010)$.

\begin{tabular}{llll} 
Compound & Conc. (\%) & Compound & Conc. (\%) \\
\hline $\mathrm{SiO}_{2}$ & 31.6 & $\mathrm{Na}_{2} \mathrm{O}$ & 1.01 \\
$\mathrm{Al}_{2} \mathrm{O}_{3}$ & 9.18 & $\mathrm{~K}_{2} \mathrm{O}$ & 0.001 \\
$\mathrm{Fe}_{2} \mathrm{O}_{3}$ & 6.78 & $\mathrm{ZnO}$ & 0.576 \\
$\mathrm{MnO}$ & 1.9 & $\mathrm{P}_{2} \mathrm{O}_{5}$ & 0.01 \\
$\mathrm{CoO}$ & 0.0032 & $\mathrm{CO}_{3}$ & 0.92 \\
$\mathrm{NiO}$ & 0.0042 & $\mathrm{Cl}^{-}$ & 1.63 \\
$\mathrm{TiO}$ & 0.0021 & $\mathrm{SO}_{4}{ }^{2-}$ & 10.8 \\
$\mathrm{CuO}$ & 0.0091 & $\mathrm{REEs}^{2-}$ & 0.0215 \\
$\mathrm{MgO}$ & 6.4 & $\mathrm{U}$ & 0.0094 \\
$\mathrm{CaO}$ & 9.2 & & \\
\hline
\end{tabular}

processes are also commonly applied for the recovery of metals from concentrated effluents (Abreu and Morais, 2014; Agrawal et al., 2000; Hou et al., 2016; Matsumiya et al., 2014; Quinn et al., 2013; Xie et al., 2014; Zhu et al., 2016). However, these expensive and hazardous reagents may have non-negligible environmental effect due to partial dissolving in the effluent and contamination of receiving water bodies. These reasons generally limit the use of solvent extraction for proces-

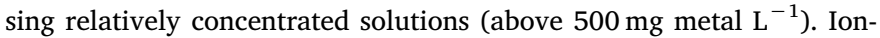
exchange and chelating resins represent interesting alternatives for the treatment of dilute effluents (Cao et al., 2013; Nghiem Van et al., 2016; Ogata et al., 2015a, b; Rahmani-Sani et al., 2015; Semnani et al., 2012; Solgy et al., 2015; Wang et al., 2002; Zagorodnyaya et al., 2013); biosorbents are a variant of synthetic resins consisting of similar binding mechanisms involving the same functional groups naturally occurring on renewable green materials (Cadogan et al., 2014; Das and Das, 2013; Guibal, 2004; Nie et al., 2015; Oliveira et al., 2012; Prodromou and Pashalidis, 2013), or functionalized materials of biological origin (Galhoum et al., 2016; Guibal et al., 1993; Mahfouz et al., 2015).

In this study, the residues from sulfuric acid leaching of multi-metal ore have been valorized applying a sequence of treatments including different leaching procedures, selective precipitation steps (using different precipitants) and a concentrating step (sorption of selected metals using a synthetic resin (Hamza and Abdel-Rahman, 2015)). This synthetic resin has been previously characterized for the binding of a series of metal ions: the resin has a particular affinity for uranyl species (probably due to the presence of amine groups) but can also adsorb other metal ions according the affinity range: $\mathrm{U}(\mathrm{VI})>\mathrm{Cu}(\mathrm{II})>\mathrm{Fe}$ (III) $>\mathrm{Zn}(\mathrm{II})>\mathrm{Pb}(\mathrm{II})>\mathrm{Th}(\mathrm{IV})>\mathrm{Ni}(\mathrm{II})>\mathrm{Cd}(\mathrm{II})>\mathrm{Co}(\mathrm{II})$

(Hamza and Abdel-Rahman, 2015). The synthesis procedure and the main physicochemical characteristics of the sorbent tested for metal recovery from the leachates of ores are first summarized (see below Section 3.1), together with the main sorption properties for uranium, base metals and neodymium from synthetic solutions. This information is derived from previous studies (Hamza and Abdel-Rahman, 2015); this can be considered for introducing the further tests on ore leachates. After metal desorption, a series of precipitation phases was used for selectively recovering REEs and uranium. A special attention was paid to the purity of the precipitated products that were characterized using EDX analysis (energy dispersive X-ray analysis).

\section{Materials and methods}

\subsection{Reagents and resin synthesis}

Uranyl nitrate, neodymium chloride and dysprosium chloride salts were supplied by Fluka AG (Buchs, Switzerland). The REE salts were burnt off at $900{ }^{\circ} \mathrm{C}$ under air atmosphere for $3 \mathrm{~h}$ before being dissolved in concentrated sulfuric acid under heating. Stock solutions were prepared at the concentration of $1 \mathrm{~g} \mathrm{~L}^{-1}$; working solutions were freshly prepared before use by dilution of stock solutions with Milli-Q water.

The synthesis of magnetic resin (constituted of a magnetite core coated with poly glutamine) has been previously described (Hamza and Abdel-Rahman, 2015). Figure AM2 (see Additional Material Section) show the synthesis route. Magnetic micro-particles were produced by hydrothermal treatment mixing Fe(II) and Fe(III) precursors under reflux at $\mathrm{pH}$ controlled between 10 and 11 . The magnetic particles were mixed with acrylonitrile and divinyl benzene before adding the initiator and pore-producing solvents to synthesize the base polymer (MPAN). The functionalization of MPAN consisted of a series of reactions with: (a) hydrazine hydrate to yield polyhydrazinyl amine (MPHA), (b) carbon disulfide to produce thion derivative (MTDT), (c) ethyl chloroacetate to synthesize acetate derivative (MTDE), (d) hydrazine hydrate to produce hydrazide derivative (MTHA), and (e) sodium nitrite (under specifically experimental conditions) to obtain MTZA (poly 1,3,4-thiadiazol-2-(3H)-thionylacetylazide) resin. The resin was then reacted with glutamine methyl ester to produce magnetic poly(methylglutamine) resin (MGLU) (Hamza and Abdel-Rahman, 2015; Hamza et al., 2018). FTIR analysis and chemical characterization have already been reported (Hamza et al., 2018). The particles were sieved and the fraction $100-200$ Mesh $(0.074-0.149 \mathrm{~mm})$ was used for the sorption experiments.

\subsection{Analytical methods}

Uranium analysis at high concentration was performed using the oxidimetric titration method against ammonium metavanadate (diphenylamine sulfonate being used as the indicator and uranium was reduced with ammonium ferrous sulfate just prior analysis) (Davies and Gray, 1964). At low concentration, U(VI) was analyzed (together with other metal ions in the leaching solution) using ICP-AES (inductively coupled plasma atomic emission spectrometry with JY Activa M spectrometer, Jobin-Yvon/Horiba, Longjumeau, France). Alternatively, metals like $\mathrm{Zn}, \mathrm{Ni}, \mathrm{Mn}, \mathrm{Pb}$ and $\mathrm{Cu}$ were analyzed using an atomic absorption spectrophotometer (Unicam AAS model 969, with wavelengths, $\lambda$ : $213.9,232,279.5,217$ and $324.8 \mathrm{~nm}$, respectively). The major oxides in the ore were quantified by the procedure of rapid silicate analysis (Shapiro, 1975): the ore was dissolved in alkaline solution for $\mathrm{SiO}_{2}$ determination and in an acid solution for the determination of $\mathrm{MgO}, \mathrm{TiO}_{2}, \mathrm{CaO}, \mathrm{Al}_{2} \mathrm{O}_{3}, \mathrm{P}_{2} \mathrm{O}_{5}, \mathrm{Fe}_{2} \mathrm{O}_{3}$ oxides (etc.). Total concentration of REEs (reacted with arsenazo III, at the concentration of $0.015 \% \mathrm{w} / \mathrm{w}$ ) was determined by visible spectrophotometry using a Shimadzu UV-160 spectrophotometer at the wavelength, $\lambda$ : $654 \mathrm{~nm}$ (Marczenko, 1986).

The precipitates obtained during the processing of ore leachates (i.e., $\mathrm{Na}_{2} \mathrm{U}_{2} \mathrm{O}_{7}, \mathrm{ZnS}, \mathrm{Al}(\mathrm{OH})_{3}, \mathrm{REE}_{2} \mathrm{O}_{3}$ ) were analyzed by SEM-EDX analysis (in addition to spectrophotometric analysis carried out on acidic dissolutions of corresponding precipitates). The final products were analyzed by X-ray micro-analyzer (Oxford 6587 INCA X-sight) connected to a JEOL JSM-5500 LV scanning electron microscope) at $20 \mathrm{kV}$ after gold coating (SPI-module sputter coater).

\subsection{Ore characterization}

The sulfuric acid treatment of pristine ore (gibbsite bearing shale collected at Abu Mogherat, South Western Sinai) has been previously described (Hamza et al., 2012). Initial grades for U and REEs (in the raw material) were $250 \mathrm{ppm}$ of $\mathrm{U}$ and $789 \mathrm{ppm}$ of REEs. The mineralogical composition of this ore material was gibbsite $\left(\mathrm{Al}(\mathrm{OH})_{3}\right.$, dolomite $(\mathrm{CaMg}$ $\left(\mathrm{CO}_{3}\right)_{2}$, iron-based minerals (including hematite $\mathrm{Fe}_{2} \mathrm{O}_{3}$ and pyrite $\mathrm{FeS}_{2}$ ); manganese was present as pyrolusite $\left(\mathrm{MnO}_{2}\right)$, chalcophanite ( $\mathrm{Zn}$ $\left.\mathrm{Mn}_{3} \mathrm{O}_{4} \cdot 3 \mathrm{H}_{2} \mathrm{O}\right)$ and Crednerite $\left(\mathrm{CuMnO}_{2} \mathrm{O}_{4}\right)$ (Hamza, 2010). After conventional leaching process with a sulfuric acid consumption of $210 \mathrm{~kg}$ $\mathrm{H}_{2} \mathrm{SO}_{4}$ per ton of ore at $22^{\circ} \mathrm{C}\left( \pm 2{ }^{\circ} \mathrm{C}\right)$, the composition of the residue (which was considered in this work as the mineral resource) was characterized (Table 1 and Fig. 1): leaching efficiency reached $62.4 \%$ 


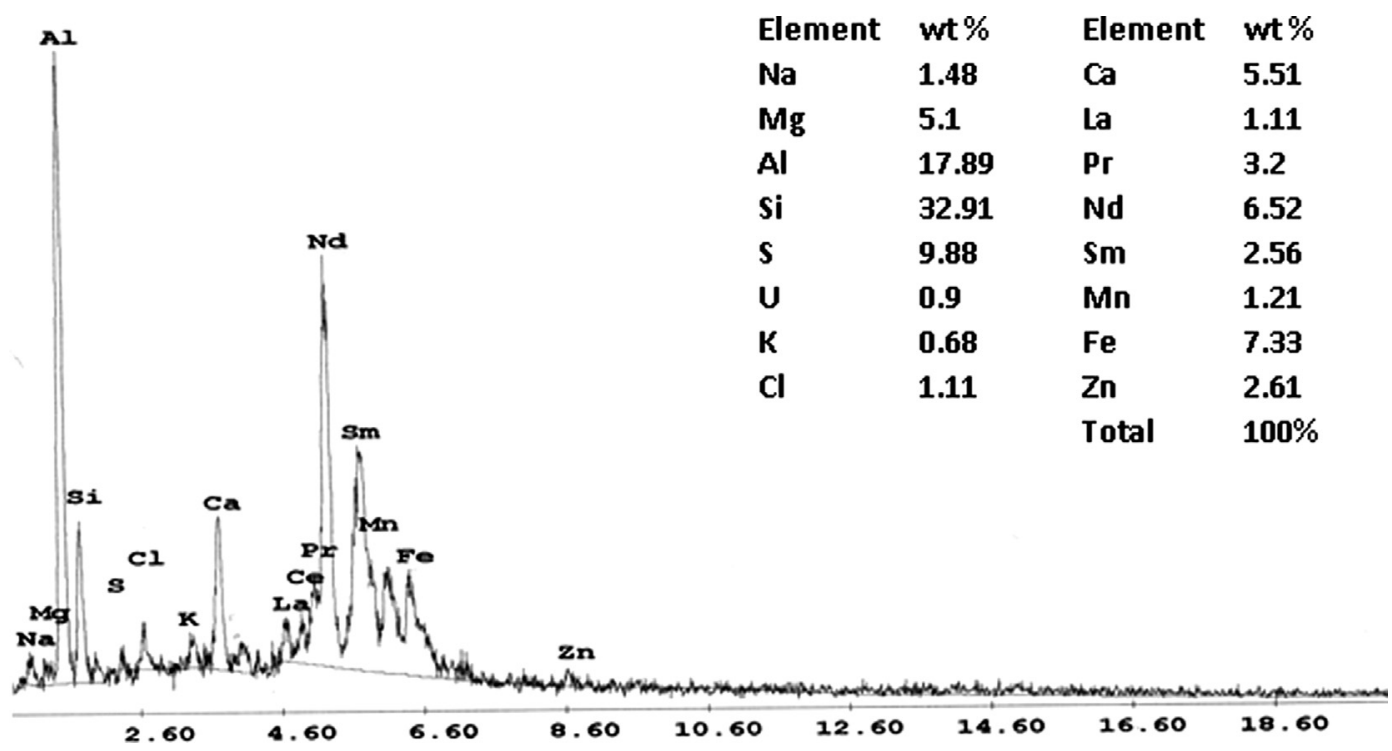

Fig. 1. EDX analysis of the reprocessed material (mining residue, herein considered as the raw material) (x-axis: energy, keV; y-axis: arbitrary unit for counts).

and $72.7 \%$ for uranium and REEs (residual levels: 94 and $215 \mathrm{ppm}$ ), respectively, while other base metals were removed at levels ranging between 55 and $80 \%$.

\subsection{Production and processing of leachates}

The leaching tests were performed using different acids (i.e., phosphoric acid, hydrochloric acid, nitric acid, and sulfuric acid) with different modes of application (i.e., agitated leaching, fixed-bed column leaching and pug leaching).

Experiments in agitated reactors were carried out by contact of $100 \mathrm{~g}$ of processed ore, in glass beaker, with different volumes of the different acids (at different concentrations, between $50 \mathrm{gL}^{-1}$ and $400 \mathrm{~g} \mathrm{~L}^{-1}$ ); the $\mathrm{S} / \mathrm{L}$ ratio varied between $1 / 2$ and $1 / 5$ while the contact time varied between $1 \mathrm{~h}$ and $6 \mathrm{~h}$, at room temperature (i.e., $25^{\circ} \mathrm{C}$ ). The leachate was recovered by filtration and the concentrations of $U$ and REEs were determined for evaluating leaching efficiency.

When the leaching was processed in column systems the processed ore $(100 \mathrm{~g})$ was disposed in glass column (internal diameter: $2 \mathrm{~cm}$ and depth: $10 \mathrm{~cm}$ ), glass wool was disposed as filters at both the bottom and top of the column (for enhancing the homogeneous distribution of the spread solution at the top of the column). Sulfuric acid (concentration 50-300 $\mathrm{g} \mathrm{L}^{-1}$ ) was pumped down-flow at the flow rate of $0.4 \mathrm{~mL} \mathrm{~min}^{-1}$. Column systems are used for simulating the heap leaching of low grade ores.

The pug leaching improves the kinetics and efficiency of metal extraction by mixing the ore with the acid under heating (curing temperature set here to $120^{\circ} \mathrm{C}$ ). In order to improve the metal extraction, the ore treated with the pug leaching was disposed in a column and a small amount of acid solution was pumped through the ore bed for recovering the leached metal solutions.

The leachates were treated by sorption for metal pre-concentration (uranium and REEs) and by precipitation using different precipitants. In order to improve the selective precipitation of metal ions the leachates were first subjected to selective separation of $\mathrm{Al}(\mathrm{III}), \mathrm{Zn}$ (II) and $\mathrm{Fe}(\mathrm{III})$ before processing to a concentration step of $\mathrm{U}(\mathrm{VI})$ and REEs(III) through sorption/desorption. Sorption experiments were performed in polyethylene flasks by mixing (at agitation speed: $300 \mathrm{rpm}$ ) for $1 \mathrm{~h}\left(\right.$ at $25^{\circ} \mathrm{C}$ ) $0.1 \mathrm{~L}(\mathrm{~V}, \mathrm{~L})$ of metal solution (initial metal concentration, $\mathrm{C}_{0}: 100 \mathrm{mg}$ metal $\left.\mathrm{L}^{-1}\right)$ with $0.01 \mathrm{~g}$ of sorbent $(\mathrm{m}, \mathrm{g})$. The $\mathrm{pH}$ of the solution was varied between 1 and 6; above $\mathrm{pH}$ 6, some REEs (such as Dy(III)) may precipitate. At equilibrium the sorbent was magnetically separated from the solution and the residual concentration $\left(\mathrm{C}_{\mathrm{eq}}, \mathrm{mg} \mathrm{L}^{-1}\right.$, or $\mathrm{mmol}$
$\mathrm{L}^{-1}$ ) was determined by ICP-AES analysis. The mass balance equation was used for calculating the sorption capacity ( $\mathrm{q}_{\mathrm{eq}}, \mathrm{mg}$ metal $\mathrm{g}^{-1}$, or mmol metal $\left.\mathrm{g}^{-1}\right)$ : $\mathrm{q}_{\mathrm{eq}}=\left(\mathrm{C}_{0}-\mathrm{C}_{\mathrm{eq}}\right) \times \mathrm{V} / \mathrm{m}$.

Metal desorption was performed using $1 \mathrm{M} \mathrm{H}_{2} \mathrm{SO}_{4}$ solutions. The eluates were then selectively precipitated by oxalic acid (recovery of REEs-oxalates further converted to metal oxides after thermal treatment, under air atmosphere) and finally by alkaline precipitation (recovery of uranium as uranate salt).

\section{Results and discussion}

3.1. Reminder on the characterization of resin properties for $U(V I)$ and $N d$ (III) recovery

The sorption properties of the magnetic resin have been previously characterized for several heavy metals (including $\mathrm{Cu}(\mathrm{II})(7.52 \mathrm{mmol} \mathrm{Cu}$ $\left.\mathrm{g}^{-1}\right), \mathrm{Zn}(\mathrm{II})$ (6.96 mmol Zn $\left.\mathrm{g}^{-1}\right)$, Fe(III) (8.06 mmol Fe $\left.\mathrm{g}^{-1}\right), \mathrm{Pb}(\mathrm{II})$ (1.98 mmol Pb g $\left.{ }^{-1}\right), \mathrm{Ni}(\mathrm{II})\left(6.65 \mathrm{mmol} \mathrm{Ni} \mathrm{g}{ }^{-1}\right), \mathrm{Cd}(\mathrm{II})(2.80 \mathrm{mmol} \mathrm{Cd}$ $\mathrm{g}^{-1}$ ) and Co(II) (4.07 mmol Co $\left.\mathrm{g}^{-1}\right)$ ), for Th(IV) (1.81 mmol Th $\mathrm{g}^{-1}$ ) and U(VI) (2.33 $\mathrm{mmol} \mathrm{U} \mathrm{g}^{-1}$ ) (Hamza and Abdel-Rahman, 2015). The maximum sorption capacities ( $\mathrm{q}_{\text {max,exp }}$, experimental values at $25^{\circ} \mathrm{C}$ ) can be roughly correlated to the radius of hydrated metal species ( $\mathrm{r}_{\text {Hydr.Metal }}$, collected from (Persson, 2010)): qmax $\exp =2.68$ $\left.\mathrm{r}_{\text {Hydr.Metal }}{ }^{-2.296}, \mathrm{R}^{2}: 0.915\right)$. In order to evaluate the possibility of this sorbent to be used for the recovery of the metal ions present in the acid leachates of the reprocessed ore, preliminary studies have been performed for characterizing the sorption properties of the functionalized magnetic resin for $\mathrm{U}(\mathrm{VI}), \mathrm{Nd}(\mathrm{III})$ and $\mathrm{Dy}(\mathrm{III})$, representative of radionuclide, light rare earth elements (LREEs) and heavy REEs (HREEs), respectively. $\mathrm{Nd}(\mathrm{III})$ sorption properties (through the evaluation of $\mathrm{pH}$ on sorption efficiency and the study of uptake kinetics) that were compared to those of $\mathrm{U}(\mathrm{VI})$ (as $\mathrm{UO}_{2}{ }^{2+}$ ). Based on the high affinity of this resin for heavy metals it is suggested removing these highly competitor ions before processing the recovery and enrichment of $\mathrm{Nd}(\mathrm{III})$ and U(VI): this will be performed by a series of selective precipitation steps (see below). The profiles will be compared for $\mathrm{Nd}(\mathrm{III})$ (representative of REE(III) family) and U(VI) for evaluating the possibility to separate these metal ions or recover them simultaneously. The main conclusions of the previous study are summarized below.

The structure of the prepared sorbent (Figure AM2, see Additional Material Section) was confirmed by FTIR analysis, elemental analysis, titration, X-ray diffraction (XRD), thermogravimetric analysis (TGA), $\mathrm{pH}_{\mathrm{PZC}}(\mathrm{pH}$ of zero-charge) and SEM characterization (Hamza et al., 
2018).

At $\mathrm{pH}$ close to 5, the deprotonation of amine groups improves metal sorption. In addition, at this $\mathrm{pH}$, other reactive groups are available (such as those based on S- and O- ligands), or become more reactive due to a change in their electronic environment (Hamza and AbdelRahman, 2015; Lebrun et al., 2014). The capacity of the three metals at $\mathrm{pH} 5$ is up to $2.185 \mathrm{mmol} \mathrm{U} \mathrm{g}^{-1}, 3.633 \mathrm{mmol} \mathrm{Nd} \mathrm{g}^{-1}$ and $3.239 \mathrm{mmol}$ Dy $\mathrm{g}^{-1}$. Figure AM3 (see Additional Material Section) shows the speciation diagrams for $\mathrm{U}(\mathrm{VI})$ and $\mathrm{Nd}(\mathrm{III}$ ) (at a concentration of $100 \mathrm{mg}$ $\mathrm{L}^{-1}$ ) as a function of $\mathrm{pH}$ (sulfate solution produced by salt dissociation and $\mathrm{pH}$ control using sulfuric acid) and at $\mathrm{pH} 5$ with increasing concentrations of sulfate anions. The calculations were performed using Visual Minteq (Gustafsson, 2013). Neodymium is predominantly cationic $\left(\mathrm{Nd}^{3+}\right.$ and $\mathrm{NdSO}_{4}{ }^{+}$): their fraction increases from $80 \%$ at $\mathrm{pH} 1$ to $100 \%$ above $\mathrm{pH} 4$, when sulfate concentration is low (below $0.2 \mathrm{M}$ ). On the opposite hand, at $\mathrm{pH} 5$, the increase in sulfate concentration drastically increases the fraction of anionic neodymium species: $\mathrm{Nd}\left(\mathrm{SO}_{4}\right)_{2}{ }^{-}$ becomes predominant at sulfate concentration higher than $0.2 \mathrm{M}$. This speciation directly influences the attraction/repulsion of metal species on protonated amine groups. In the case of uranyl, the speciation is much more complex due to the presence of several polynuclear and polyhydrolyzed species in addition to sulfate-based species. At low sulfate concentration (below $0.12 \mathrm{M}$ ), neutral sulfate-based uranium species predominate in acidic solutions; when the $\mathrm{pH}$ increases uranyl sulfate species are progressively disappearing with formation of free uranyl species and at the highest $\mathrm{pH}$ with predominance of polynuclear, polyhydrolyzed species. At $\mathrm{pH} 5$, the increase of the concentration of sulfate makes uranyl-sulfate species predominate in the solution (at sulfate concentration higher than $0.2 \mathrm{M}$ ). This is especially important for the sorption of uranium from $\mathrm{H}_{2} \mathrm{SO}_{4}$ leachate solutions; under these conditions $\mathrm{UO}_{2}\left(\mathrm{SO}_{4}\right)_{2}{ }^{2-}$ is the predominant species. The analysis of the speciation of metal anions in sulfate-containing solutions shows that at $\mathrm{pH}$ below 1.5 the anionic species are negligible and the protonated amine groups of the magnetic resin can hardly bind uranyl and neodymium ions. The suspected anion-exchange reactions are thus poorly probable:

$$
\begin{aligned}
& \mathrm{RNH}_{2}+\mathrm{H}_{2} \mathrm{SO}_{4} \leftrightarrow \mathrm{RNH}_{3}{ }^{+} \cdot \mathrm{HSO}_{4}{ }^{-} \\
& 2 \mathrm{RNH}_{3}{ }^{+} \cdot \mathrm{HSO}_{4}{ }^{-}+\left(\mathrm{UO}_{2}\right)\left(\mathrm{SO}_{4}\right)_{2}{ }^{2-} \leftrightarrow\left(\mathrm{RNH}_{3}+\right)_{2} \cdot \mathrm{UO}_{2}\left(\mathrm{SO}_{4}\right)_{2}{ }^{2-}+2 \\
& \mathrm{HSO}_{4}{ }^{-}
\end{aligned}
$$$$
2 \mathrm{RNH}_{3}{ }^{+} \cdot \mathrm{HSO}_{4}{ }^{-}+\mathrm{Nd}\left(\mathrm{SO}_{4}\right)_{2}{ }^{-} \leftrightarrow\left(\mathrm{RNH}_{3}{ }^{+}\right)_{2} \cdot \mathrm{Nd}\left(\mathrm{SO}_{4}\right)_{2}{ }^{-}+2 \mathrm{HSO}_{4}{ }^{-}
$$

The pH-edges for $\mathrm{U}(\mathrm{VI})$ and $\mathrm{Nd}(\mathrm{III})$ are very close and it is not possible separating $\mathrm{U}(\mathrm{VI})$ from $\mathrm{Nd}(\mathrm{III})$ by sorption on the resin on the basis of $\mathrm{pH}$ selection. However, the resin has high affinity for these metal ions and the sorbent can be used for concentrating the target metals from dilute solutions (such as the concentrations obtained in the leaching of reprocessed ores).

A contact time of $1 \mathrm{~h}$ is sufficient to reach equilibrium. The pseudofirst-order rate equation (PFORE) better describes uptake kinetics for the three metal ions than the pseudo-second-order rate equation (PSORE). The uptake kinetics at $\mathrm{pH} 5$ have been compared for U(VI) and $\mathrm{Nd}(\mathrm{III})$ using the magnetic resin. The equilibrium is reached very fast: $45 \mathrm{~min}$ are sufficient for both $\mathrm{U}(\mathrm{VI})$ and $\mathrm{Nd}(\mathrm{III})$ recovery. It is noteworthy that the sorption capacity linearly increases with time: the reaction is following a pseudo-zero order rate equation. The slope (and then the apparent kinetic parameter) is higher for $\mathrm{Nd}(\mathrm{III})$ than for $\mathrm{U}$ (VI): $0.092 \mathrm{mmol} \mathrm{g}^{-1} \mathrm{~min}^{-1}$ and $0.052 \mathrm{mmol} \mathrm{g}^{-1} \mathrm{~min}^{-1}$ for $\mathrm{Nd}(\mathrm{III})$ and $\mathrm{U}(\mathrm{VI})$, respectively. The higher affinity of the sorbent for $\mathrm{Nd}(\mathrm{III})$ than for U(VI) may explain the faster kinetics; however, the molar concentration for $\mathrm{Nd}(\mathrm{III})$ being higher than that of $\mathrm{U}(\mathrm{VI})$ contributes to higher concentration gradient between the solution and the internal reactive groups (impact on resistance to mass transfer and diffusion mechanisms). The differences are thus not enough marked to make possible the separation of the metal ions by kinetic control.

The sorption isotherms at $\mathrm{pH} 5$ are efficiently modeled by the Langmuir and the Sips equations. The Langmuir equation fits relatively well experimental data: the calculated maximum sorption capacities are consistent with the experimental values (reported above).

The complete separation of metal ions from multi-component solutions is relatively difficult to achieve and the separation properties strongly depend on $\mathrm{pH}$. The sorbent has a relatively high selectivity for U(VI) than for REEs (especially higher against Dy(III) (HREEs) than Nd (III) (LREEs)) at $\mathrm{pH} \mathrm{2,} 2.92$ and 3.62, while at $\mathrm{pH} 4.5$ and 5.3, the selectivity is more favorable to REEs against U(VI). In other words, the sorbent preferentially binds $\mathrm{U}(\mathrm{VI})$ in acidic solutions while at near neutral $\mathrm{pH}$ the REEs will be preferentially adsorbed.

Acidic solutions (such as $0.5 \mathrm{~mol} \mathrm{~L}^{-1} \mathrm{HCl}$ ) are very effective for removing metal ions from loaded sorbent; sorption and desorption properties are remarkably stable for a minimum of 5 cycles of sorption/ desorption.

\subsection{Leaching of ore residue}

The ore that was previously treated with sulfuric acid (acid consumption: $210 \mathrm{~kg} \mathrm{H}_{2} \mathrm{SO}_{4}$ per ton at $22^{\circ} \mathrm{C}$ ) represents the mining residue that will be treated for complementary metal recovery using three leaching processes (i.e., agitated leaching, column leaching and pug leaching). The evaluation of leaching performance was focused in a first step on the recovery of uranyl and rare-earth metals. The composition of this mining residue has been reported in Table 1 and on Fig. 1 (EDX analysis). More specifically, the contents of U(VI) and REEs in the mining residue were $94 \mathrm{ppm}$ and $215 \mathrm{ppm}$, respectively. The strategy for investigating the acidic leaching of ore residue consisted in successive steps: (a) pre-selection of the acid, (b) evaluation of the effect of acid concentration. This preliminary study was carried out on either stirred tank reactor or fixed-bed column systems. In a second phase of the study the pug leaching was used for optimizing the process with a study focused on sulfuric acid concentration (selecting a cure temperature of $120^{\circ} \mathrm{C}$ ). Target metals for evaluating leaching performance were $\mathrm{U}(\mathrm{VI})$ and REEs(III) for strategic elements, $\mathrm{Zn}(\mathrm{II})$ as a representative of heavy metals and $\mathrm{Al}(\mathrm{III})$ giving an overview of the behavior of most representative mineral compound of the ore.

\subsubsection{Preliminary study of experimental parameters - from stirred tank reactor to fixed-bed column system}

This first step in the study of the leaching of mining residue consisted of testing different types of acids for the evaluation of REE(III) and U(VI) leaching. The leaching was performed at the temperature of $25^{\circ} \mathrm{C}$ and the consumption of the acid was set to $540 \mathrm{~kg}$ acid per ton of ore residue. The reaction was performed under strong agitation (higher than $300 \mathrm{rpm}$ ) for $3 \mathrm{~h}$ with a solid/liquid ratio close to $1: 3$. Table 2 reports the leaching efficiency for the different systems. The most efficient leaching acid is $\mathrm{HNO}_{3}$ with leaching yields close to $63 \%$ for both REEs and U. Phosphoric acid is more selective for the recovery of REEs (leaching efficiency higher than $70 \%$ while uranyl is poorly leached, close to $28 \%$ ). Hydrochloric acid and sulfuric acid have comparable leaching performances (in the range $48-57 \%$ for REEs and U). Taking into account the leaching efficiency, the cost and availability of these

\section{Table 2}

Effect of the acid used for ore reprocessing for U(VI) and REEs(III) leaching at $25^{\circ} \mathrm{C}$ (acid/ consumption per ton of ore: $540 \mathrm{~kg}$; agitated leaching;S/L: 1:3; T: $25^{\circ} \mathrm{C}$; contact time: $3 \mathrm{~h}$ ).

\begin{tabular}{lll}
\hline Acid & REEs(III) leaching efficiency (\%) & U(VI) leaching efficiency (\%) \\
\hline $\mathrm{HCl}$ & 54 & 57 \\
$\mathrm{H}_{2} \mathrm{SO}_{4}$ & 48 & 53 \\
$\mathrm{H}_{3} \mathrm{PO}_{4}$ & 71 & 28 \\
$\mathrm{HNO}_{3}$ & 63 & 64
\end{tabular}


Table 3

Effect of sulfuric acid concentration on column leaching process of U(VI), REEs (III), $\mathrm{Al}(\mathrm{III})$ and $\mathrm{Zn}$ (II) on reprocessed ore sample at $25^{\circ} \mathrm{C}$ (for $100 \mathrm{~g}$ of ore).

\begin{tabular}{lllllll}
\multirow{2}{*}{$\begin{array}{l}\text { Conc. } \\
\left(\mathrm{g} \mathrm{L}^{-1}\right)\end{array}$} & Volume (L) & $\begin{array}{l}\text { Acid consumption } \\
\text { (g acid/kg) }\end{array}$ & \multicolumn{5}{l}{\begin{tabular}{l} 
Leaching efficiency (\%) \\
\cline { 4 - 7 } \cline { 4 - 7 }
\end{tabular}} & & & $\mathrm{U}(\mathrm{VI})$ & $\mathrm{REEs}(\mathrm{III})$ & $\mathrm{Al}(\mathrm{III})$ & $\mathrm{Zn}(\mathrm{II})$ \\
\hline 50 & $3 \mathrm{~L}$ & 150 & 33.0 & 35.0 & 5.8 & 10.1 \\
100 & 2.5 & 250 & 48.0 & 47.0 & 11.9 & 13.1 \\
150 & 2.2 & 330 & 55.0 & 61.0 & 12.1 & 14.8 \\
200 & 2.1 & 420 & 67.4 & 70.8 & 12.9 & 18.9 \\
250 & 2.1 & 525 & 78.8 & 78.9 & 14.1 & 23.1 \\
300 & 2 & 600 & 83.0 & 82.9 & 15.5 & 29.9 \\
\hline
\end{tabular}

acids, sulfuric acid was preferred for the continuation of the work on leaching process. In addition, this acid has a limited impact on metal sorption performance for metal recovery on quaternary amine resin (Merritt, 1971). Chloride and nitrate ions may induce competition effect for the binding of $\mathrm{U}(\mathrm{VI})$ ions onto quaternary ammonium resins at low concentration and may even elute the $\mathrm{U}(\mathrm{VI})$ ions from loaded resins (IAEA, 1993). The relatively poor efficiency of leaching process in agitated tank may be attributed to the presence of clays that can contribute to re-adsorb the metals from the leachates during the stationary filtration step (Helfferich, 1995; Juri et al., 2017; Majone et al., 1993; Yong and Phadungchewit, 1993; Zaki et al., 2017). In order to avoid this problem and to increase the leaching efficiency, the next step consisted of testing the leaching process in column reactor.

The effect of the concentration of sulfuric acid on the leaching of $U$ (VI), REEs(III), Al(III) and Zn(II) was tested in column at $25^{\circ} \mathrm{C}$. Table 3 summarizes the volumes of leachate produced, the acid consumptions per ton of reprocessed ore and the leaching efficiencies when varying the concentration of the acid from 50 to $300 \mathrm{~g} \mathrm{~L}^{-1}$. The leaching profiles of U(VI) and REEs(III) are very close and more favorable than for $\mathrm{Al}(\mathrm{III})$ and $\mathrm{Zn}$ (II) extraction (much lower leaching efficiency). At low $\mathrm{H}_{2} \mathrm{SO}_{4}$ concentration (i.e., $50-100 \mathrm{~g} \mathrm{H}_{2} \mathrm{SO}_{4} \mathrm{~L}^{-1}$ ) the leaching efficiency for strategic metals is less than $50 \%$ and the dissolving of heavy metals remains very low (below 15\%). As the concentration increases, U(VI) and REEs(III) are progressively more efficiently leached (up to 83\%) while $\mathrm{Al}(\mathrm{III})$ dissolving stabilizes below $16 \%$ and $\mathrm{Zn}$ (II) leaching does not exceed $30 \%$. Above a concentration of $200 \mathrm{gL}^{-1}$ the acid consumption exceeds $420 \mathrm{~kg}$ per ton of ore; the process becomes less competitive despite a slightly higher metal recovery. The economic/ technical balance is probably close to $200-250 \mathrm{~g} \mathrm{H}_{2} \mathrm{SO}_{4} \mathrm{~L}^{-1}$ (i.e., acid consumption: $420-525 \mathrm{~kg}$ per ton of ore).

The comparison of Tables 2 and 3 shows that for approximately the same acid consumption (i.e., $525-540 \mathrm{~kg} \mathrm{H}_{2} \mathrm{SO}_{4}$ per ton of ore) the column process is more efficient than the agitation process: leaching efficiency raises around $79 \%$ for $\mathrm{U}(\mathrm{VI})$ and REEs(III) vs. around $50 \%$ for the agitation process. The column system is more efficient and less energy consuming (pump vs agitator mechanical consumption). The next step for increasing metal recovery consisted of evaluating the pug leaching of the ore residue; the impact of sulfuric acid on metal release was measured and compared to stirred tank and fixed-bed column systems.

\subsubsection{Pug leaching}

In order to improve the efficiency of the metal recovery, pug leaching was carried out making profit of the improvement of metal dissolution with increasing the temperature of the reaction. The curing temperature was set to $120^{\circ} \mathrm{C}$ and the acid consumption was varied between 100 and $400 \mathrm{~kg} \mathrm{H}_{2} \mathrm{SO}_{4}$ per ton of ore. Table 4 summarizes the leaching efficiencies for U(VI), REEs(III), Al(III) and Zn(II). As expected with the elevated temperature, the dissolution of metals is significantly improved, even at low acid consumption: at $150 \mathrm{~kg} \mathrm{H}_{2} \mathrm{SO}_{4}$ per ton of ore, the recovery of metals exceeds the level reached in column process. With an acid consumption close to $200 \mathrm{~kg} \mathrm{H}_{2} \mathrm{SO}_{4}$ per ton of ore the
Table 4

Effect of sulfuric acid concentration on pug leaching of U(VI), REEs(III), Al(III) and $\mathrm{Zn}(\mathrm{II})$ on reprocessed ore sample at $120^{\circ} \mathrm{C}$ (curing temperature).

\begin{tabular}{lllll}
\hline \multirow{2}{*}{ Acid consumption (g acid/kg) } & \multicolumn{4}{l}{ Leaching efficiency (\%) } \\
\cline { 2 - 5 } & U(VI) & REEs(III) & Al(III) & Zn(II) \\
\hline 100 & 55.2 & 54.1 & 17.1 & 21.2 \\
150 & 70.7 & 71.1 & 29.3 & 54.8 \\
197.5 & 95.0 & 94.0 & 44.4 & 85.4 \\
250 & 96.1 & 95.5 & 46.2 & 87.1 \\
300 & 96.8 & 96.1 & 46.7 & 90.0 \\
400 & 97.4 & 97.8 & 46.8 & 91.1 \\
\hline
\end{tabular}

metals are almost completely recovered: about $95 \%$ for U(VI) and REEs (III) around $44 \%$ for $\mathrm{Al}$ (III) and close to $85 \%$ for $\mathrm{Zn}$ (II). Increasing the acid consumption hardly enhances metal recovery; by less than 3-6\%, depending on the metal. It is noteworthy that the pug leaching for the same acid consumption has a significantly higher efficiency for leaching the 4 target metals.

This is a good technical/economic compromise. And the selected process consisted of mixing the ore residue with a $15 \%$ sulfuric acid (w/ w) before curing at $120^{\circ} \mathrm{C}$ for $3 \mathrm{~h}$. The sludge was then disposed in a column (column diameter: $5 \mathrm{~cm}$; column depth: $55 \mathrm{~cm}$ ) and a $50 \mathrm{~g}$ $\mathrm{H}_{2} \mathrm{SO}_{4} \mathrm{~L}^{-1}$ solution (around $960 \mathrm{~mL}$ per $\mathrm{kg}$ of ore) was sprayed at the top of the column (flow rate: $1 \mathrm{~mL} \mathrm{~min}^{-1}$ ) to facilitate the leaching of the metals. At the bottom of the column a volume of $950 \mathrm{~mL}$ of pregnant leaching solutions (PLS) at $\mathrm{pH} 0.5$ was collected. The concentrations of the metal ions in the PLS are reported in Table 5. The residual amounts of $U$ and REEs in the treated ore do not exceed $4.4 \mathrm{ppm}$ and $12.3 \mathrm{ppm}$, respectively. This means that the final residue is significantly depleted in $\mathrm{U}$ and safe for disposal.

\subsection{Treatment of acidic leachates}

Table 5 shows the composition of the PLS, which is characterized by huge amounts of $\mathrm{Al}(\mathrm{III}), \mathrm{Fe}(\mathrm{III}), \mathrm{Zn}(\mathrm{II})\left(5-40 \mathrm{~g} \mathrm{~L}^{-1}\right)$; other major elements are also present, such as $\mathrm{Na}(\mathrm{I}), \mathrm{Mn}(\mathrm{II}), \mathrm{Ca}(\mathrm{II}), \mathrm{Mg}(\mathrm{II})$ and $\mathrm{Cl}^{-}$. Other elements have concentrations lower than $200 \mathrm{mg} \mathrm{L}^{-1}$. The presence of high concentrations of $\mathrm{Zn}(\mathrm{II}), \mathrm{Fe}(\mathrm{III})$ and $\mathrm{Al}(\mathrm{III})$ may have a strong impact on the sorption performance of the resin for the recovery of valuable metals. In addition, at these levels of concentration, a sorption process is not appropriate and competitive since the expected enrichment ratio will be very low for these high levels of concentration. For this reason, it is suggested processing a selective precipitation of these metals before recovering and concentrating valuable metals by sorption and desorption steps.

\subsection{1. $\mathrm{Zn}$ (II) recovery}

$\mathrm{Zn}(\mathrm{II})$ is first precipitated using ammonium sulfide: $30-35 \mathrm{~mL}$ of $20 \%$ ammonium sulfide solution were added dropwise per L of PLS. In order to prevent the further dissolution of the precipitate a volume of

Table 5

Composition of the leach liquor after pug leaching process (acid consumption: $200.5 \mathrm{~g}$ sulfuric acid/ $\mathrm{kg}$ ore; temperature: $120^{\circ} \mathrm{C}$; produced leach liquor; $950 \mathrm{~mL}$; pH of leach liquor: 0.5 ).

\begin{tabular}{llll}
\hline Element & Concentration $\left(\mathrm{mg} \mathrm{L}^{-1}\right)$ & Element & Concentration $\left(\mathrm{mg} \mathrm{L}^{-1}\right)$ \\
\hline $\mathrm{Al}$ & 40689 & $\mathrm{Cu}$ & 54.3 \\
$\mathrm{Fe}$ & 20150 & $\mathrm{Ni}$ & 25.5 \\
$\mathrm{Mn}$ & 989 & $\mathrm{Ti}$ & 13.2 \\
$\mathrm{Ca}$ & 366 & $\mathrm{U}$ & 89.3 \\
$\mathrm{Mg}$ & 225 & $\mathrm{Co}$ & 19.8 \\
$\mathrm{Na}$ & 1430 & REEs & 203.3 \\
$\mathrm{~K}$ & 40 & $\mathrm{Cl}$ & 1340 \\
$\mathrm{Zn}$ & 4920 & & \\
\end{tabular}




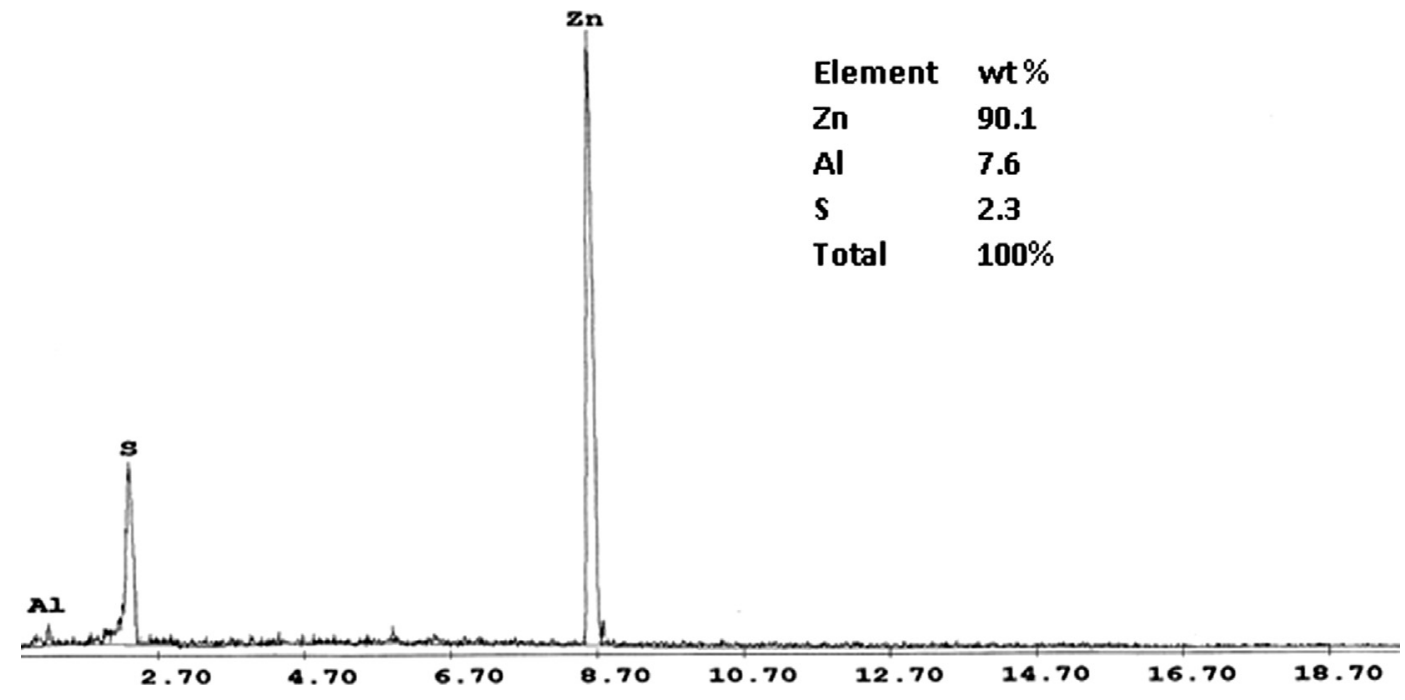

Fig. 2. EDX analysis of $\mathrm{ZnS}$ precipitate (x-axis: energy, keV; y-axis: arbitrary unit for counts).

acetic acid (about $6.5-7 \mathrm{~mL}$ ) was systematically added to each liter volume of PLS (Svehla, 1996). The metal is precipitated as a ZnS (dark yellowish precipitate), which is recovered by filtration and dried at $150^{\circ} \mathrm{C}$. The analysis of the dry precipitate by SEM-EDX showed that the precipitate mainly consists of $\mathrm{Zn}(90.1 \%)$ with traces of $\mathrm{Al}$ and S elements (2.3\% and 6.7\%, respectively) (Fig. 2).

\subsection{2. $\mathrm{Fe}$ (III) recovery}

The next step in the treatment of PLS consisted of the precipitation of $\mathrm{Fe}(\mathrm{III})$ using ammonium hydroxide $(28 \%$, w/w). The $\mathrm{pH}$ was adjusted with the alkaline solution to $\mathrm{pH} 4$ (Svehla, 1996). A brown precipitate is produced. The suspension is filtrated, dried and analyzed by SEM-EDX (Fig. 3). The precipitate is mainly constituted of Fe (85\%) and $\mathrm{Al}(7 \%)$, although some traces of $\mathrm{Na}, \mathrm{Ca}, \mathrm{Mg}$ and $\mathrm{Zn}$ elements can be detected (total fraction: $8 \%$ ).

\subsubsection{Al(III) recovery}

The separation of $\mathrm{Al}(\mathrm{III})$ is obtained by the control of the $\mathrm{pH}$ of the residual solution (filtrate) at $\mathrm{pH} 5$ using ammonium hydroxide $(28 \%$, $\mathrm{w} / \mathrm{w})$. A white precipitate is obtained. The presence of sulfide and acetate ions is supposed to contribute to enhancing $\mathrm{Al}(\mathrm{III})$ precipitation
(Shapiro, 1975):

$\mathrm{Al}^{3+}+3 \mathrm{NH}_{3}+3 \mathrm{H}_{2} \mathrm{O} \leftrightarrow \mathrm{Al}(\mathrm{OH})_{3, \mathrm{~s}}+3 \mathrm{NH}_{4}{ }^{+}$

$2 \mathrm{Al}^{3+} 3 \mathrm{~S}^{-}+6 \mathrm{H}_{2} \mathrm{O} \leftrightarrow 2 \mathrm{Al}(\mathrm{OH})_{3, \mathrm{~s}}+3 \mathrm{H}_{2} \mathrm{~S}$

$\mathrm{Al}^{3+}+3 \mathrm{CH}_{3} \mathrm{COO}^{-}+2 \mathrm{H}_{2} \mathrm{O} \leftrightarrow \mathrm{Al}(\mathrm{OH})_{2}{ }^{+} \cdot \mathrm{CH}_{3} \mathrm{COO}_{\mathrm{s}}^{-}+2 \mathrm{CH}_{3} \mathrm{COOH}$

Fig. 4 shows the SEM-EDX analysis of the precipitate that mainly contains $\mathrm{Al}$ and $\mathrm{S}$ elements, and some traces of $\mathrm{Na}$ and $\mathrm{Si}$ elements. Table 6 gives the composition of the precipitated PLS (after successive selective precipitation steps). The concentrations of U(VI) and REEs(III) are very close to the initial concentrations in the plug leachates; actually the losses of $\mathrm{U}(\mathrm{VI})$ and REEs(III) do not exceed 1.8 and $0.5 \%$, respectively.

3.3.4. REE(III) and U(VI) recovery from PPLS and enrichment by sorption/ desorption

Uranyl and REEs(III) are separated from the precipitated PLS (PPLS) by sorption/desorption sequence (Hamza et al., 2018). Since these metals are well sorbed on the magnetic resin (without selectivity, see above) this operation is only supposed to enrich the concentration of

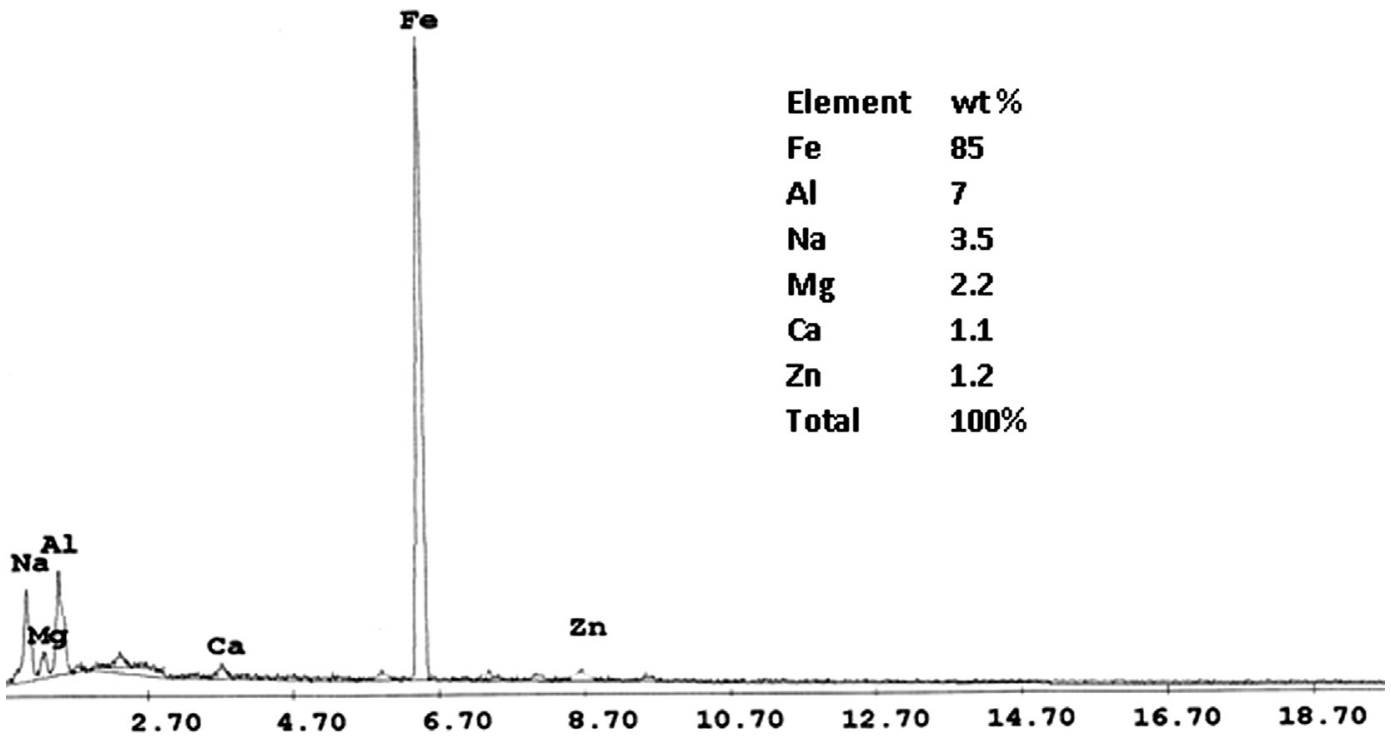

Fig. 3. EDX analysis of $\mathrm{Fe}(\mathrm{OH})_{3}$ precipitate (x-axis: energy, keV; y-axis: arbitrary unit for counts). 


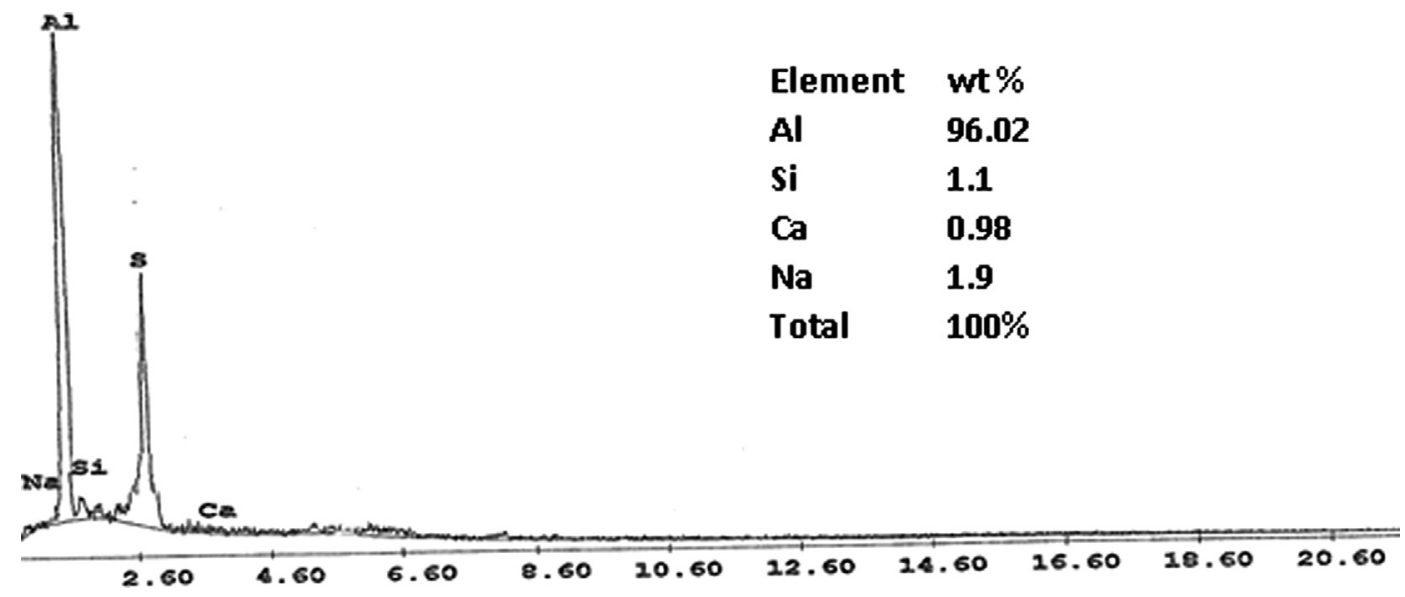

Fig. 4. EDX analysis of $\mathrm{Al}(\mathrm{OH})_{3}$ precipitate (x-axis: energy, keV; y-axis: arbitrary unit for counts).

Table 6

Composition of the PLS after selective precipitation steps.

\begin{tabular}{llll}
\hline Element & Concentration $\left(\mathrm{mg} \mathrm{L}^{-1}\right)$ & Element & Concentration $\left(\mathrm{mg} \mathrm{L}^{-1}\right)$ \\
\hline $\mathrm{U}$ & 79.9 & $\mathrm{Zn}$ & 50 \\
$\mathrm{REEs}$ & 183.5 & $\mathrm{Cu}$ & 42.5 \\
$\mathrm{Al}$ & 109 & $\mathrm{Ni}$ & 17.1 \\
$\mathrm{Fe}$ & 105 & $\mathrm{Co}$ & 13.3 \\
\hline
\end{tabular}

these metal ions in the eluate (and to separate these metals from other metal traces). The separation of uranyl ions from REEs has been carried out in the eluate through selective precipitation steps (see below). A volume of $10 \mathrm{~L}$ of treated PLS (at $\mathrm{pH} \mathrm{5}$, after successive precipitation steps) is mixed with $10 \mathrm{~g}$ of the magnetic resin for $1 \mathrm{~h}$. The residual concentrations in the solution reach $0.7 \mathrm{mg} \mathrm{U} \mathrm{L}^{-1}$ and $6.8 \mathrm{mg} \mathrm{REE}$ $\mathrm{L}^{-1}$.The sorption capacities reach up to $77.2 \mathrm{mg} \mathrm{U} \mathrm{g}^{-1}$ (i.e., $0.32 \mathrm{mmol}$

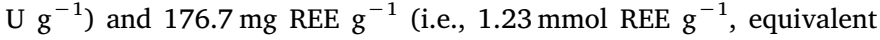
$\mathrm{Nd}$ ). These values are about $17 \%, 34 \%$ and $33 \%$ of maximum sorption capacities for U(VI), Nd(III) and Dy(III) obtained for the treatment of synthetic pure solution.

The desorption of metals is performed by contact, under agitation, of the metal-loaded resin with $500 \mathrm{~mL}$ of $1 \mathrm{M}$ sulfuric acid for $1 \mathrm{~h}$. After solid/liquid separation the concentrations of U(VI) and REEs in the eluate reach $1530 \mathrm{mg} \mathrm{U} \mathrm{L}^{-1}$ and $3502 \mathrm{mg} \mathrm{REE} \mathrm{L}^{-1}$. This means that the sorption/desorption allowed an enrichment factor close to 19 .

\subsubsection{Selective precipitation of $U(V I)$ and REEs(III) from eluates for metal} separation

The eluates are treated by successive selective precipitations for separating U(VI) from REEs(III). Oxalic acid is well known for its ability to precipitate REEs(III) (Abreu and Morais, 2010; Liu et al., 2008; Tunsu et al., 2016). Indeed, REEs(III) form stable insoluble oxalate complexes in acidic solutions while U(VI) ions remain soluble in this kind of solutions:

$2 \mathrm{REE}(\mathrm{III})+3 \mathrm{H}_{2} \mathrm{C}_{2} \mathrm{O}_{4} \leftrightarrow \mathrm{REE}_{2} \cdot\left(\mathrm{C}_{2} \mathrm{O}_{4}\right)_{3, \mathrm{~s}}+6 \mathrm{H}^{+}$

Oxalic acid is added to the eluates (at final concentration: $25 \%$, w/ $\mathrm{w}$ ) and the $\mathrm{pH}$ of the solution is controlled to different $\mathrm{pH}$ values in the range $0.8-4$ for $1 \mathrm{~h}$. The precipitation takes place in the reactor and after $1 \mathrm{~h}$ of contact the precipitate is settled; the residual concentrations of U(VI) and REEs(III) are analyzed and the efficiencies of precipitation are calculated. Fig. 5 shows the effect of pH on the precipitation of REEs (III) and $\mathrm{U}(\mathrm{VI})$. In the case of $\mathrm{U}(\mathrm{VI})$, the precipitation begins at $\mathrm{pH}$ higher than 3 (at $\mathrm{pH} 4$ the precipitation does not exceed 10\%). On the opposite hand, the precipitation of REEs(III) is strongly dependent on the $\mathrm{pH}$ : the precipitation efficiency sharply increases between $\mathrm{pH} 0.8$ and $\mathrm{pH} 1.5$ before progressively decreasing. Optimum precipitation of

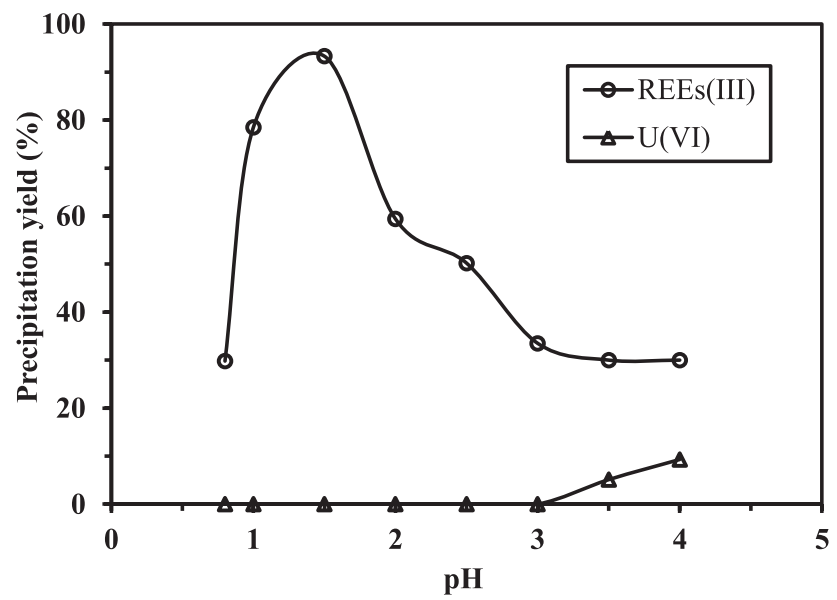

Fig. 5. Effect of $\mathrm{pH}$ on the selective precipitation of U(VI) and REEs using $25 \%$ oxalic acid solutions, at $25^{\circ} \mathrm{C}$.

REEs(III) is obtained at pH 1.5 (yield > 93\%). This is consistent with literature (Woyski and Harris, 1963). At this pH, REEs(III) are selectively precipitated (U(VI) ions remain soluble in the eluate). Increasing the concentration of oxalic acid improves the precipitation of REEs(III) (without affecting U(VI) precipitation) at pH 1.5 (Fig. 6). Under selected experimental conditions (composition of the eluate) the optimum concentration of oxalic acid is 25\%: REEs(III) are completely

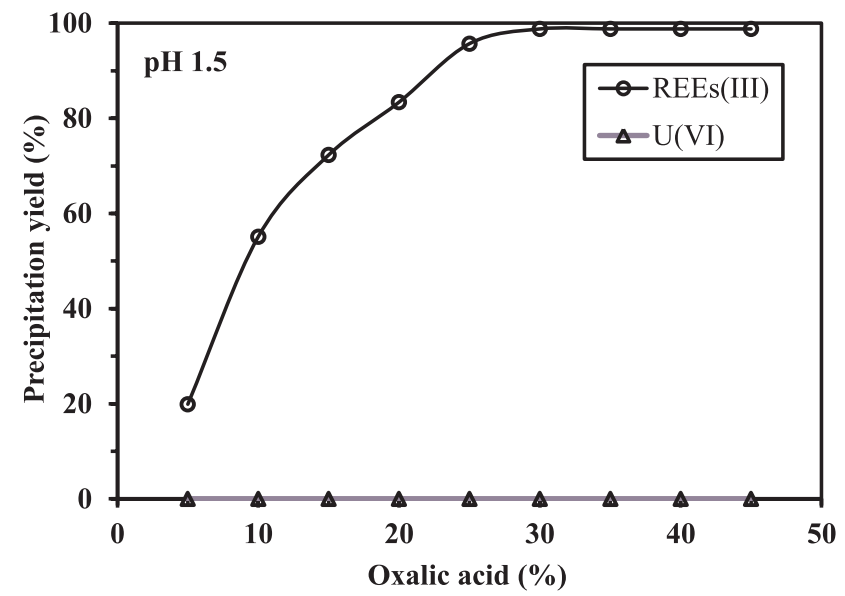

Fig. 6. Effect of oxalic acid concentration on the selective precipitation of U(VI) and REEs at $\mathrm{pH} 1.5$, at $25^{\circ} \mathrm{C}$. 


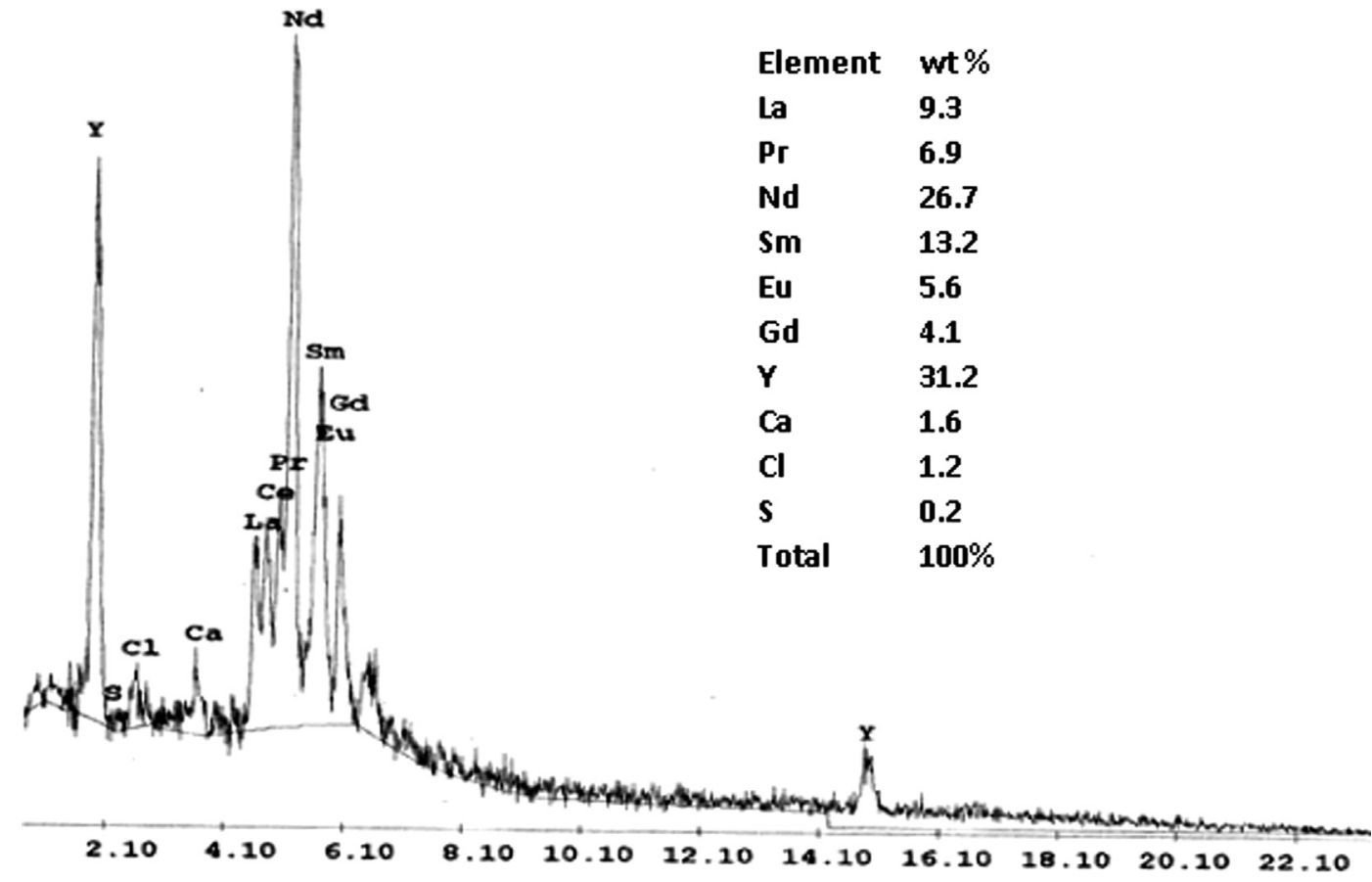

Fig. 7. EDX analysis of REEs(III) precipitate (x-axis: energy, keV; y-axis: arbitrary unit for counts).

precipitated. The REEs(III)/oxalic acid precipitate was recovered by filtration, rinsed, dried and finally converted into its oxide form by thermal degradation in air at $850^{\circ} \mathrm{C}$ for $2 \mathrm{~h}$. The residue was analyzed spectrophotometrically after being dissolved in acid solution. The mass balance shows a recovery efficiency by precipitation close to $97 \%$. The SEM-EDX analysis shows, apart REEs (Y, La, Ce, Pr, Nd, Sm, Eu and Gd), the presence of traces of $\mathrm{Ca}, \mathrm{S}$ and $\mathrm{Cl}$ elements (Fig. 7). It is noteworthy that REEs(III) can be efficiently precipitated as insoluble phosphate complexes (Beltrami et al., 2015): in the presence of low excess of phosphate, the precipitation is relatively selective against Fe(III). This would be an interesting alternative to oxalate in order to reduce the release of carbon dioxide during the calcination of REE(III)/oxalate complexes at the end of the recovery process; this would make the process more environmentally friendly.

Uranium was recovered from the filtrate by precipitation with $\mathrm{NaOH}$ at $\mathrm{pH}$ 9. Sodium diuranate $\left(\mathrm{Na}_{2} \mathrm{U}_{2} \mathrm{O}_{7}\right)$ is collected by filtration and dried at $110^{\circ} \mathrm{C}$ for $3 \mathrm{~h}$. The spectrophotometric analysis and the SEM-EDX characterization show that U purity reaches $91.7 \%$; some traces of $\mathrm{Na}$ and $\mathrm{Cl}$ elements are identified while REEs cannot be detected (Fig. 8). Alternative processes can be used for uranium precipitation (or purification) of these precipitates using other precipitants such as saturated magnesia or ammonia (AbowSlama et al., 2014).

\subsection{Flowsheet for the treatment of mining residue}

The flowsheet for the treatment of ore residue can be roughly summarized according to Fig. 9. The amount of acid used for the recovery of valuable metals is relatively important (around $200 \mathrm{~kg} \mathrm{H}_{2} \mathrm{SO}_{4}$ per ton); however, this is less than the levels used for the recovery of heavy metals from an analogous ore material as reported by El Hazek et al. (2008) (i.e., around $1600 \mathrm{~kg}$ of $\mathrm{H}_{2} \mathrm{SO}_{4}$ per ton).

In the Annex of the Additional Material Section a summary of the distribution of metal ions in the different compartments of the process (initial precipitation steps, resin fixed-bed column processing and final selective precipitation steps) is reported (at each step) and as a global distribution (compared to the amounts of metals recovered in the PLS). This allows identifying where the different dissolved metals are recovered or lost in the flowsheet. Zinc is recovered at $96.4 \%$ in the initial

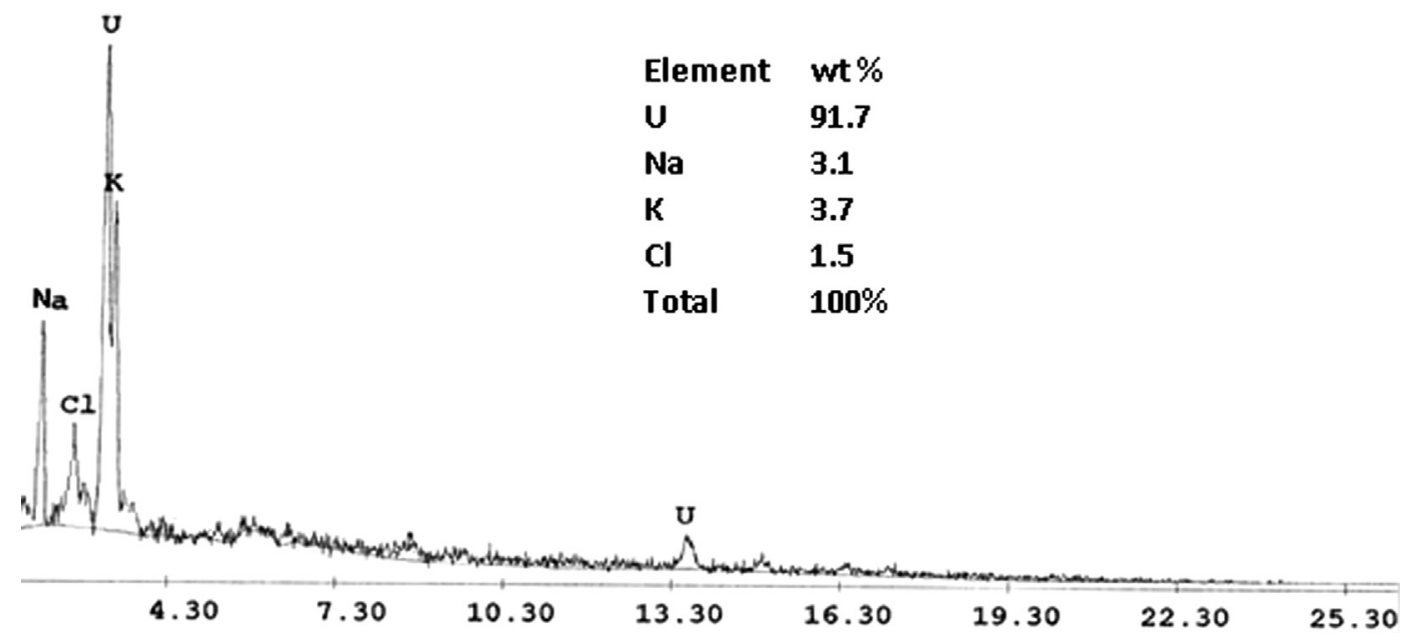

Fig. 8. EDX analysis of U(VI) precipitate (x-axis: energy; keV, y-axis: arbitrary unit for counts). 


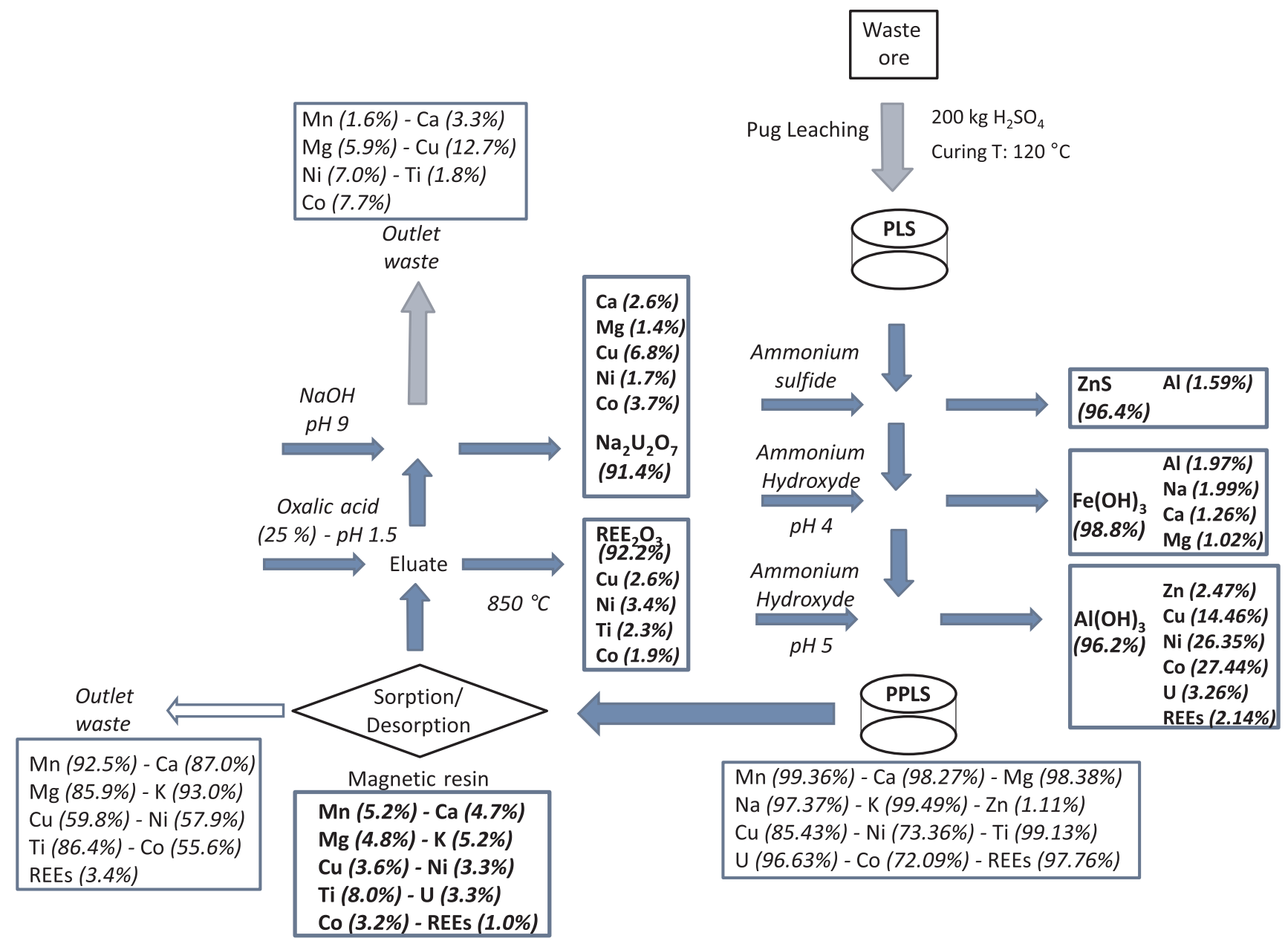

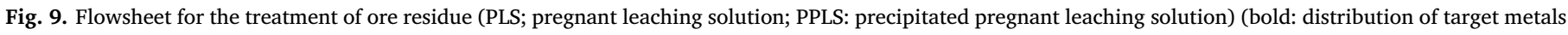

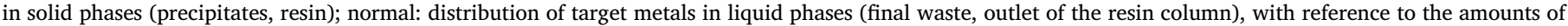
metals extracted from the ores in the PLS).

precipitation step; Fe is removed at $98.8 \%$ in the relevant precipitation step while $96.2 \%$ of $\mathrm{Al}$ is removed in the selective precipitation step. About $91.4 \%$ of $\mathrm{U}$ is recovered in the final $\mathrm{NaOH}$ precipitation step while $92.2 \%$ of REEs was removed during the oxalate precipitation step. Other base metals (present in much lower concentrations) are distributed in different compartments; these low concentrations may explain that they are negligible in terms of mass fractions in the precipitates of $\mathrm{Zn}(\mathrm{II}), \mathrm{Al}(\mathrm{III})$ and $\mathrm{Fe}(\mathrm{III})$. For example, $\mathrm{Cu}$ appears in $\mathrm{Al}$ precipitation step (14.5\%), at the outlet of the resin column (59.8\%), in the waste effluent $(12.7 \%)$ and in much lower proportions in the resin and the other precipitates. Nickel, Co, and Ti have roughly the same behavior than $\mathrm{Cu}$. Manganese, $\mathrm{Mg}, \mathrm{Ca}$ and $\mathrm{K}$ are almost completely released in the outlet of the resin column. The Annex also reports a summary of the reagents needed for the treatment of a standard 1-kg amount of ore. A rough evaluation of costs (in terms of reagent use) is provided. Obviously, a more complete and accurate evaluation of costs (including energy expenses and operating man-power costs) would be useful for considering the feasibility of $U$ and REEs recoveries from these tailings. Taking only in account the amounts and costs of the reagents for (a) leaching, (b) use both in sorption/desorption, and (c) refined metal precipitate, the expenditures are close to $2.38 \mathrm{USD} / \mathrm{kg}$ (see Additional Material Section for complementary discussion of cost analysis). The cost of synthesis of the sorbent ( $10 \mathrm{~g}$ necessary for the treatment of $1 \mathrm{~kg}$ of ore) is close to 24.2 USD (at the lab scale). The recycling of the sorbent for several sorption/desorption cycles minimizes the impact of this expenditure on the total cost of recovery of valuable metals. More complete economic evaluation would be necessary for concluding on the conditions and constraints for competitive use of this integrated process.

\section{Conclusion}

Ore residue from metal extraction issued from Abu Mogherate district has been successfully reprocessed for recovering additional valuable metals. The optimization of the leaching procedure shows that the most efficient method consists of pug leaching the ore residue at a curing temperature of $120^{\circ} \mathrm{C}$ with a $15 \%$ (w/w) sulfuric acid concentration (and additional washing of the material disposed in column reactor using sulfuric acid solution). For an acid consumption of $197.5 \mathrm{~kg} \mathrm{H}_{2} \mathrm{SO}_{4}$ per ton of ore residue, the leaching efficiencies reach up to $95 \%$ and $94 \%$ for $U$ and REEs, respectively, in addition to other valuable metals such as $\mathrm{Al}$ and $\mathrm{Zn}$. Each ton of ore residue produces 950 $\mathrm{L}$ of pregnant leach solution that contains up to $89 \mathrm{mg} \mathrm{U} \mathrm{L}^{-1}$ and $202 \mathrm{mg} \mathrm{REE} \mathrm{L}^{-1}$ at $\mathrm{pH} 0.5$.

A series of precipitation steps, including successively ammonium sulfide, ammonium hydroxide at $\mathrm{pH} 4$ and ammonium hydroxide at $\mathrm{pH}$ 5, allows separating $\mathrm{Zn}(\mathrm{II}), \mathrm{Fe}(\mathrm{III})$ and $\mathrm{Al}(\mathrm{III})$ with relatively high purity (superior to 90\%). The precipitated PLS issued from these precipitation steps can be treated by sorption/desorption on a magnetic resin, with an enrichment factor close to 19 for both U(VI) and REEs(III). The eluates of the process can be valorized by selective precipitation of REEs (III) using $25 \%$ oxalate solution at $\mathrm{pH} 1.5$, followed by $\mathrm{U}(\mathrm{VI})$ 
precipitation as $\mathrm{Na}_{2} \mathrm{U}_{2} \mathrm{O}_{7}$ (sodium diuranate) with $\mathrm{NaOH}$ at pH 9. SEMEDX analysis of the different precipitates shows purity grade superior to 93\% (and more specifically REE(III)-oxalate precipitate free of U). The final residue is also uranium-depleted, limiting the impact of the material disposal on the environment.

The integrated process developed in this work allows recovering added values from low-grade ores or from tailings. This is a strategic objective. However, this economic benefit may be also considered a way for balancing the cost of treatment for contaminating material: the objective may be to reduce the fingerprint of stored hazardous wastes (depleted uranium, removal of toxic elements, etc.).

\section{Acknowledgments}

This work was supported by the French Government through a fellowship granted to Mohammed F. Hamza by the French Embassy in Egypt (Institut Francais d'Egypte). Authors are grateful for IFE and Egyptian Academy of Scientific Research and Technology (Egypt) for funding the IMHOTEP project (Metal Valor, Ref. 39529QA) Authors also thank the technical support of Thierry Vincent and André Brun (C2MA, IMT - Mines Ales).

\section{Appendix A. Supplementary material}

Supplementary data to this article can be found online at https:// doi.org/10.1016/j.mineng.2019.01.008.

\section{References}

Abhilash, R., Singh, S., Mehta, K.D., Kumar, V., Pandey, B.D., Pandey, V.M., 2009. Dissolution of uranium from silicate-apatite ore by Acidithiobacillus ferrooxidans. Hydrometallurgy 95 (1-2), 70-75.

AbowSlama, E.H.Y., Ebraheem, E., Sam, A.K., 2014. Precipitation and purification of uranium from rock phosphate. J. Radioanal. Nucl. Chem. 299 (1), 815-818.

Abreu, R.D., Morais, C.A., 2010. Purification of rare earth elements from monazite sulphuric acid leach liquor and the production of high-purity ceric oxide. Miner. Eng. 23 (6), 536-540.

Abreu, R.D., Morais, C.A., 2014. Study on separation of heavy rare earth elements by solvent extraction with organophosphorus acids and amine reagents. Miner. Eng. 61, $82-87$.

Agrawal, Y.K., Shrivastav, P., Menon, S.K., 2000. Solvent extraction, separation of uranium (VI) with crown ether. Sep. Purif. Technol. 20 (2-3), 177-183.

Aydin, F.A., Soylak, M., 2007. A novel multi-element coprecipitation technique for separation and enrichment of metal ions in environmental samples. Talanta 73 (1), 134-141.

Beltrami, D., Deblonde, G.J.P., Bélair, S., Weigel, V., 2015. Recovery of yttrium and lanthanides from sulfate solutions with high concentration of iron and low rare earth content. Hydrometallurgy 157, 356-362.

Binnemans, K., Jones, P.T., Blanpain, B., Van Gerven, T., Pontikes, Y., 2015. Towards zero-waste valorisation of rare-earth-containing industrial process residues: a critical review. J. Cleaner Prod. 99, 17-38.

Biswas, S., Rupawate, V.H., Hareendran, K.N., Roy, S.B., Chakravartty, J.K., 2015. Novel precipitation technique for uranium recovery from carbonate leach solutions. J. Radioanal. Nucl. Chem. 304 (3), 1345-1351.

Borra, C.R., Pontikes, Y., Binnemans, K., Van Gerven, T., 2015. Leaching of rare earths from bauxite residue (red mud). Miner. Eng. 76, 20-27.

Brisson, V.L., Zhuang, W.-Q., Alvarez-Cohen, L., 2016. Bioleaching of rare earth elements from monazite sand. Biotechnol. Bioeng. 113 (2), 339-348.

Burns, A.D., Abbasi, P., Dreisinger, D.B., 2016. Uranous sulfate precipitation as a novel hydrometallurgical process for uranium purification. Hydrometallurgy 163, 49-54.

Cadogan, E.I., Lee, C.-H., Popuri, S.R., Lin, H.-Y., 2014. Efficiencies of chitosan nanoparticles and crab shell particles in europium uptake from aqueous solutions through biosorption: Synthesis and characterization. Int. Biodeterior. Biodegrad. 95, 232-240.

Cao, Q., Liu, Y., Kong, X., Zhou, L., Guo, H., 2013. Synthesis of phosphorus-modified poly (styrene-co-divinylbenzene) chelating resin and its adsorption properties of uranium (VI). J. Radioanal. Nucl. Chem. 298 (2), 1137-1147.

Charalampides, G., Vatalis, K.I., Apostoplos, B., Ploutarch-Nikolas, B., 2015. Rare earth elements: Industrial applications and economic dependency of Europe. Procedia Econ. Finance 24, 126-135.

Das, N., Das, D., 2013. Recovery of rare earth metals through biosorption: An overview. J. Rare Earths 31 (10), 933-943.

Davies, W., Gray, W., 1964. A rapid and specific titrimetric method for the precise determination of uranium using iron(II) sulphate as reductant. Talanta 11 (8), 1203-1211.

El Hazek, M.N., Ahmed, F.Y., El Kasaby, M.A., Attia, R.M., 2008. Sulfuric acid leaching of polymetallic Abu Zeneima gibbsite-shale. Hydrometallurgy 90 (1), 34-39.

Gabriel, S., Baschwitz, A., Mathonniere, G., Eleouet, T., Fizaine, F., 2013. A critical assessment of global uranium resources, including uranium in phosphate rocks, and the possible impact of uranium shortages on nuclear power fleets. Ann. Nucl. Energy $58,213-220$.

Galhoum, A.A., Mahfouz, M.G., Atia, A.A., Gomaa, N.A., Abdel-Rehem, S.S., Vincent, T., Guibal, E., 2016. Alanine and serine functionalized magnetic nano-based particles for sorption of Nd(III) and Yb(III). Adv. Environ. Res. 5 (1), 1-18.

Guibal, E., 2004. Interactions of metal ions with chitosan-based sorbents: a review. Sep. Purif. Technol. 38 (1), 43-74.

Guibal, E., Saucedo, I., Roussy, J., Roulph, C., Lecloirec, P., 1993. Uranium sorption by glutamate glucan - a modified chitosan. 2. Kinetic-studies. Water SA 19 (2), 119-126.

Gustafsson, J.P., 2013. Visual MINTEQ, ver. 3.1, ver. 3.1 ed. KTH, Royal Institute of Technology, (url: https://vminteq.lwr.kth.se/; accessed May 2017), Stockholm, Sweden.

Hamza, M.F., 2010. Synthesis and application of chelating amidoxime/amidoxime acrylic acid resins for purification and concentration of uranium and rare earth elements from low grade ore. In: Department of Chemistry, Faculty of Science. Menoufia University, Shebein El-Kom, Egypt.

Hamza, M.F., Abdel-Rahman, A.A.H., 2015. Extraction studies of some hazardous metal ions using magnetic peptide resins. J. Dispersion Sci. Technol. 36 (3), 411-422.

Hamza, M.F., Abdel-Rahman, A.A.H., Guibal, E., 2018. Magnetic glutamine-grafted polymer for the sorption of U(VI), Nd(III) and Dy(III). J. Chem. Technol. Biotechnol. 93 (6), 1790-1806.

Hamza, M.F., El Aassy, I.E., Ahmed, F.Y., Abdel-Rahman, A.A.H., Atta, A.M., 2012. Separation of uranium and rare earth elements with high purity from low-grade gibbsite-bearing shale ore by different chelating resins. J. Dispersion Sci. Technol. 33 (4), 482-489.

Haque, N., Hughes, A., Lim, S., Vernon, C., 2014. Rare earth elements: overview of mining, mineralogy, uses, sustainability and environmental impact. Resources 3 (4), 614.

Helfferich, F.G., 1995. Ion Exchange. Dover Publications Inc, New York, NY (USA).

Hou, H., Xu, J., Wang, Y., Chen, J., 2016. Solvent extraction of lanthanum and cerium ions from hydrochloric acidic aqueous solutions using partly saponified 2-ethylhexyl phosphonic acid mono-2-ethylhexyl ester. Chin. J. Chem. Eng. 24 (1), 79-85.

IAEA, 1993. Uranium extraction technology. In: Technical Report Series. IAEA, Vienna (Austria), p. 380 .

Juri, O.O., Akinwumi, I.I., Oluwatuyi, O.E., 2017. Nigerian lateritic clay soils as hydraulic barriers to adsorb metals. geotechnical characterization and chemical compatibility. Environ. Prot. Eng. 43 (4), 209-222.

Kikot, P., Viera, M., Mignone, C., Donati, E., 2010. Study of the effect of pH and dissolved heavy metals on the growth of sulfate-reducing bacteria by a fractional factorial design. Hydrometallurgy 104 (3-4), 494-500.

Lebrun, C., Starck, M., Gathu, V., Chenavier, Y., Delangle, P., 2014. Engineering short peptide sequences for uranyl binding. Chem. Eur. J. 20 (50), 16566-16573.

Liu, Z.G., Li, M., Hu, Y.H., Wang, M.T., Shi, Z.X., 2008. Preparation of large particle rare earth oxides by precipitation with oxalic acid. J. Rare Earths 26 (2), 158-162.

Mahfouz, M.G., Galhoum, A.A., Gomaa, N.A., Abdel-Rehem, S.S., Atia, A.A., Vincent, T., Guibal, E., 2015. Uranium extraction using magnetic nano-based particles of diethylenetriamine-functionalized chitosan: Equilibrium and kinetic studies. Chem. Eng. J. 262, 198-209.

Majone, M., Papini, M.P., Rolle, E., 1993. Clay adsorption of lead from landfill leachate. Environ. Technol. 14 (7), 629-638.

Marczenko, Z., 1986. Separation and Spectrophotometric Determination of Elements, second ed. Ellis Horwood, Chichester, UK.

Matsumiya, M., Kikuchi, Y., Yamada, T., Kawakami, S., 2014. Extraction of rare earth ions by tri-n-butylphosphate/phosphonium ionic liquids and the feasibility of recovery by direct electrodepositiori. Sep. Purif. Technol. 130, 91-101.

Merritt, R.C., 1971. The Extractive Metallurgy of Uranium. 1971, Colorado School of Mines Research Institute, [Golden].

Mirjalili, K., Roshani, M., 2007. Resin-in-pulp method for uranium recovery from leached pulp of low grade uranium ore. Hydrometallurgy 85 (2-4), 103-109.

Mishra, A., Pradhan, N., Kar, R.N., Sukla, L.B., Mishra, B.K., 2009. Microbial recovery of uranium using native fungal strains. Hydrometallurgy 95 (1-2), 175-177.

Nettleton, K.C.A., Nikoloski, A.N., Da Costa, M., 2015. The leaching of uranium from betafite. Hydrometallurgy 157, 270-279.

Nghiem Van, N., Iizuka, A., Shibata, E., Nakamura, T., 2016. Study of adsorption behavior of a new synthesized resin containing glycol amic acid group for separation of scandium from aqueous solutions. Hydrometallurgy 165, 51-56.

Nie, X.-Q., Dong, F.-Q., Liu, N., Zhang, D., Liu, M.-X., Yang, J., Zhang, W., 2015. Biosorption and biomineralization of uranium(VI) from aqueous solutions by Landoltia punctata. Spectrosc. Spectral Anal. 35 (9), 2613-2619.

Ogata, T., Narita, H., Tanaka, M., 2015a. Adsorption behavior of rare earth elements on silica gel modified with diglycol amic acid. Hydrometallurgy 152, 178-182.

Ogata, T., Narita, H., Tanaka, M., 2015b. Rapid and selective recovery of heavy rare earths by using an adsorbent with diglycol amic acid group. Hydrometallurgy 155, 105-109.

Oliveira, R.C., Guibal, E., Garcia Jr., O., 2012. Biosorption and desorption of lanthanum (III) and neodymium(III) in fixed-bed columns with Sargassum sp.: Perspectives for separation of rare earth metals. Biotechnol. Progr. 28 (3), 715-722.

Panda, R., Kumari, A., Jha, M.K., Hait, J., Kumar, V., Kumar, J.R., Lee, J.Y., 2014. Leaching of rare earth metals (REMs) from Korean monazite concentrate. J. Ind. Eng. Chem. 20 (4), 2035-2042.

Persson, I., 2010. Hydrated metal ions in aqueous solution: How regular are their structures? Pure Appl. Chem. 82 (10), 1901-1917.

Prodromou, M., Pashalidis, I., 2013. Uranium adsorption by non-treated and chemically modified cactus fibres in aqueous solutions. J. Radioanal. Nucl. Chem. 298 (3), 1587-1595. 
Quinn, J.E., Wilkins, D., Soldenhoff, K.H., 2013. Solvent extraction of uranium from saline leach liquors using DEHPA/Alamine 336 mixed reagent. Hydrometallurgy 134, $74-79$.

Rahmani-Sani, A., Hosseini-Bandegharaei, A., Hosseini, S.H., Kharghani, K., Zarei, H., Rastegar, A., 2015. Kinetic, equilibrium and thermodynamic studies on sorption of uranium and thorium from aqueous solutions by a selective impregnated resin containing carminic acid. J. Hazard. Mater. 286, 152-163.

Satybaldiyev, B., Lehto, J., Suksi, J., Tuovinen, H., Uralbekov, B., Burkitbayev, M., 2015. Understanding sulphuric acid leaching of uranium from ore by means of U-234/U238 activity ratio as an indicator. Hydrometallurgy 155, 125-131.

Semnani, F., Asadi, Z., Samadfam, M., Sepehrian, H., 2012. Uranium(VI) sorption behavior onto amberlite CG-400 anion exchange resin: Effects of pH, contact time, temperature and presence of phosphate. Ann. Nucl. Energy 48, 21-24.

Shapiro, L., 1975. Rapid analysis of silicate, carbonate, and phosphate rocks, In Bulletin, ed. U.S. Geol. Surv. Bull., Vol. 76, pIII, Report Number 1401, p. Pp. 88.

Solgy, M., Taghizadeh, M., Ghoddocynejad, D., 2015. Adsorption of uranium(VI) from sulphate solutions using Amberlite IRA-402 resin: Equilibrium, kinetics and thermodynamics study. Ann. Nucl. Energy 75, 132-138.

Svehla, G., 1996. Vogel's Qualitative Inorganic Analysis, 7th ed. Addison Wesley Longman Ltd, Harlow (England).

Tunsu, C., Lapp, J.B., Ekberg, C., Retegan, T., 2016. Selective separation of yttrium and europium using Cyanex 572 for applications in fluorescent lamp waste processing. Hydrometallurgy 166, 98-106.

Tunsu, C., Petranikova, M., Gergoric, M., Ekberg, C., Retegan, T., 2015. Reclaiming rare earth elements from end-of-life products: A review of the perspectives for urban mining using hydrometallurgical unit operations. Hydrometallurgy 156, 239-258.

USEPA, 2012. Rare Earth Elements: A Review of Production, Processing, Recycling, and Associated Environmental Issues. Engineering Technical Support Center Land Remediation and Pollution Control Division National Risk Management Research Laboratory Office of Research and Development, U.S.EPA, Cincinnati (OH), USA, p. 135 .
Van Roy, S., Vanbroekhoven, K., Dejonghe, W., Diels, L., 2006. Immobilization of heavy metals in the saturated zone by sorption and in situ bioprecipitation processes. Hydrometallurgy 83 (1-4), 195-203.

Wang, Z.H., Ma, G.X., Lu, J., Liao, W.P., Li, D.Q., 2002. Separation of heavy rare earth elements with extraction resin containing 1-hexyl-4-ethyloctyl isopropylphosphonic acid. Hydrometallurgy 66 (1-3), 95-99.

Watling, H.R., 2015. Review of biohydrometallurgical metals extraction from polymetallic mineral resources. Minerals 5 (1), 1-60.

Weterings, K., Janssen, J., 1985. Recovery of uranium, vanadium, yttrium, and rareearths from phosphoric-acid by a precipitation method. Hydrometallurgy 15 (2) 173-190.

Woyski, M.M., Harris, R.E., 1963. The rare earths and rare earth compounds. Part II, Vol 8. In: Kolthoff, I.M. (Ed.), Treatise on Analytical Chemistry. John Wiley \& Sons, New York, USA, pp. 1-146.

Xie, F., Zhang, T.A., Dreisinger, D., Doyle, F., 2014. A critical review on solvent extraction of rare earths from aqueous solutions. Miner. Eng. 56 (-), 10-28.

Yong, R.N., Phadungchewit, Y., 1993. pH influence on selectivity and retention of heavy metals in some clay soils. Can. Geotech. J. 30 (5), 821-833.

Yoon, H.S., Kim, C.J., Chung, K.W., Kim, S.D., Kumar, J.R., 2015. Recovery process development for the rare earths from permanent magnet scraps leach liquors. J. Braz. Chem. Soc. 26 (6), 1143-1151.

Zagorodnyaya, A.N., Abisheva, Z.S., Sharipova, A.S., Sadykanova, S.E., Bochevskaya, Y.G., Atanova, O.V., 2013. Sorption of rhenium and uranium by strong base anion exchange resin from solutions with different anion compositions. Hydrometallurgy $131,127-132$

Zaki, A.A., Ahmad, M.I., Abd El-Rahman, K.M., 2017. Sorption characteristics of a landfill clay soil as a retardation barrier of some heavy metals. Appl. Clay Sci. 135, 150-167.

Zammit, C.M., Brugger, J., Southam, G., Reith, F., 2014. In situ recovery of uranium - the microbial influence. Hydrometallurgy 150, 236-244.

Zhu, Z.W., Pranolo, Y., Cheng, C.Y., 2016. Uranium recovery from strong acidic solutions by solvent extraction with Cyanex 923 and a modifier. Miner. Eng. 89, 77-83. 